Stefan Neumeier^, Yulia Arinicheva, Yaqi Ji, Julia M. Heuser, Piotr M. Kowalski, Philip Kegler, Hartmut Schlenz, Dirk Bosbach and Guido Deissmann

\title{
New insights into phosphate based materials for the immobilisation of actinides
}

https://doi.org/10.1515/ract-2017-2819

Received May 8, 2017; accepted August 21, 2017; published online October 12, 2017

\begin{abstract}
This paper focuses on major phosphate-based ceramic materials relevant for the immobilisation of $\mathrm{Pu}$, minor actinides, fission and activation products. Key points addressed include the recent progress regarding synthesis methods, the formation of solid solutions by structural incorporation of actinides or their non-radioactive surrogates and waste form fabrication by advanced sintering techniques. Particular attention is paid to the properties that govern the long-term stability of the waste forms under conditions relevant to geological disposal. The paper highlights the benefits gained from synergies of state-of-the-art experimental approaches and advanced atomistic modeling tools for addressing properties and stability of $f$-element-bearing phosphate materials. In conclusion, this article provides a perspective on the recent advancements in the understanding of phosphate based ceramics and their properties with respect to their application as nuclear waste forms.
\end{abstract}

* Corresponding author: Stefan Neumeier, Forschungszentrum Jülich $\mathrm{GmbH}$, Institute of Energy and Climate Research - Nuclear Waste Management and Reactor Safety (IEK-6), 52425 Jülich, Germany; and JARA High-Performance Computing, Schinkelstrasse 2, 52062 Aachen, Germany, E-mail: s.neumeier@fz-juelich.de

Yulia Arinicheva: Forschungszentrum Jülich $\mathrm{GmbH}$, Institute of Energy and Climate Research - Nuclear Waste Management and Reactor Safety (IEK-6), 52425 Jülich, Germany; JARA HighPerformance Computing, Schinkelstrasse 2, 52062 Aachen, Germany; and Forschungszentrum Jülich, Institute of Energy and Climate Research - Materials Synthesis and Processing (IEK-1), 52425 Jülich, Germany

Yaqi Ji, Piotr M. Kowalski, Philip Kegler, Hartmut Schlenz, Dirk Bosbach and Guido Deissmann: Forschungszentrum Jülich $\mathrm{GmbH}$, Institute of Energy and Climate Research - Nuclear Waste Management and Reactor Safety (IEK-6), 52425 Jülich, Germany; JARA High-Performance Computing, Schinkelstrasse 2, 52062 Aachen, Germany

Julia M. Heuser: Forschungszentrum Jülich $\mathrm{GmbH}$, Institute of Energy and Climate Research - Nuclear Waste Management and Reactor Safety (IEK-6), 52425 Jülich, Germany; JARA High-Performance Computing, Schinkelstrasse 2, 52062 Aachen, Germany; and Karlsruhe Institute of Technology, Institute for Applied Materials (IAM), 76021 Karlsruhe, Germany
Keywords: Phosphate ceramics, nuclear waste forms, actinides immobilization.

\section{Introduction - general aspects}

The safe disposal of radioactive wastes requires the longterm isolation of the waste from the biosphere to protect humans and the environment against dangers arising from ionising radiation. At the scientific and technical level, it is generally accepted that waste disposal in deep geological repositories is the safest and most sustainable option for the management of high-level radioactive wastes (HLW), such as spent nuclear fuel or reprocessing wastes e.g. nuclear waste glasses, compacted wastes etc. (e.g. [1-3]). Nuclear waste forms for the conditioning of specific radioactive waste streams or separated radionuclides must comply with various requirements including long-term durability and leaching resistance while containing a sufficiently high waste load. Depending on the nature of the waste streams that have to be immobilised, waste forms have to offer chemical flexibility to accommodate a wide range of radionuclides and impurities as well as retain daughter nuclides in the decay chains. Heat generation due to the decay of radionuclides and self-heating by release of stored Wigner-energy (resulting from structural changes inflicted by radiation damage) requires an appropriate thermal stability and thermal conductivity of the waste form. Moreover, a waste form has to exhibit a high tolerance against damages arising from self-irradiation from the incorporated radionuclides such as amorphisation of a crystalline waste matrix, which may cause an enhanced leachability of the waste form. In addition, a sufficient resistance against adverse effects induced, for example, by the build-up of helium from $\alpha$-decay and associated pressure build-up and mechanical disruption of the matrix is essential. Another important issue is the homogenous distribution of fissile radionuclides in the matrix and criticality control, i.e. the potential for incorporation of neutron absorbers into the waste form. The waste form should be resistant against recovery of radioactive constituents, especially fissile materials such as ${ }^{239} \mathrm{Pu}$ or ${ }^{235} \mathrm{U}$, to reduce proliferation risks. A reliable, safe 
and mature fabrication technology is required. In this context, low processing temperatures are advantageous to avoid losses of relatively volatile radionuclides into the off-gas. A key issue for the post-closure safety is the dissolution behaviour and leaching resistance of the waste form under the environmental conditions encountered in the long-term disposal facility and the radionuclide release rates. Radionuclide release rates constitute the source term for the subsequent radionuclide migration in the near- and far-field of the disposal site. In general, any waste form considered e.g. glasses or ceramics etc., offers distinctive strengths and weaknesses and no immobilisation matrix can satisfy all of the requirements.

In the 1980s, ceramics and borosilicate glasses were discussed competitively for the immobilisation of HLW. In 1981, the United States government made the decision to use borosilicate glasses as the preferred waste matrix for the immobilisation of HLW at Savannah River Laboratory $[4,5]$ mainly because of the chemical flexibility and existing fabrication processes of glasses. Worldwide, borosilicate glass was established as the preferred waste form for spent nuclear fuel reprocessing and was under investigation for intermediate level waste (ILW) streams.

Ceramic waste forms can be tailor-made for the immobilisation of specific radioactive waste streams consisting of single elements or element groups with similar chemical properties [6-11]. Due to the fact that specific waste streams already exist, e.g. iodine collected in filters of the exhaust from reprocessing processes and weaponsgrade $\mathrm{Pu}$, or can arise from selective waste separation processes by liquid-liquid extraction, ceramic materials are of particular interest for their immobilisation. Moreover, the application of advanced industrial scale sintering techniques, such as hot isostatic pressing, offered opportunities to immobilise HLW and ILW unsuitable for vitrification, e.g. Tc- and I-rich waste streams [12, 13], in ceramic waste forms. In the last decades, numerous single- and polyphase ceramic materials have been examined as potential nuclear waste forms for the immobilisation of specific nuclear waste streams. These include separated $\mathrm{Pu}$ from civilian or military sources unsuitable for further use, separated minor actinides $(\mathrm{MA}=\mathrm{Am}, \mathrm{Cm}, \mathrm{Np})$ and separated fission products (Cs, I, Tc) from HLW concentrate [9-11, 14-18]. In addition to oxide based ceramics e.g. polyphase Synroc materials or single-phase zirconolite, perovskite, and pyrochlore ceramics, special attention has been paid to silicates like zircon $\left(\mathrm{ZrSiO}_{4}\right)$ and/or thorite $\left(\mathrm{ThSiO}_{4}\right)$ and phosphates such as monazite, beside various other phases $[7,8,19,20]$. Complementary to the development of ceramic waste forms for actinides, specific ceramic matrices for the immobilisation of long-lived fission products such as ${ }^{135} \mathrm{Cs}$ (half-life $T_{1 / 2}=3 \cdot 10^{6}$ years)
$[21,22],{ }^{99} \mathrm{Tc}\left(T_{1 / 2}=2.1 \cdot 10^{5}\right.$ years $)[21,23]$ or ${ }^{129} \mathrm{I}\left(T_{1 / 2}=1.57 \cdot 10^{7}\right.$ years) $[24,25]$ based inter alia on the structures of hollandite, perovskite and apatite have been developed and investigated in recent years.

For many years, phosphate-based ceramic materials, particularly monazites, were subjected to extensive studies for their suitability as nuclear waste forms. These materials were of interest due to their specific physicochemical properties $[17,18]$ including high structural flexibility allowing for significant waste loadings [17, 26], high chemical durability $[17,27,28]$ and high resilience against radiation damage [29-31].

This paper reviews the main phosphate based ceramic materials relevant for the immobilisation of $\mathrm{Pu}$, minor actinides, fission and activation products. Particular attention will be paid to the discussion of recent achievements gained in international R\&D activities. For instance, synthesis methods and waste form fabrication using advanced sintering techniques, structure elucidation and properties evaluation as well as the progress developing atomistic modeling tools addressing properties and stability of $f$-element-bearing phosphate materials will be discussed. The emphasis is placed on the formation of solid solutions by structural incorporation of actinides or their non-radioactive surrogates and properties that govern the long-term stability of the waste form under conditions relevant to geological disposal including thermodynamic stability, radiation resistance and aqueous durability.

\section{Phosphate ceramics relevant for radioactive waste immobilisation}

Large varieties of phosphate-based ceramic materials exist and offer a broad structural flexibility for the incorporation of cations. The cations have various size and valence states on defined lattice sites of the crystal structure, cf. Table 1. The main focus of research activities reported in this paper have been devoted to study the structural incorporation of tri- and tetravalent actinides in phosphate compounds with monazite and cheralite structure and to the investigation of their properties. Additionally, thorium phosphates, britholites, apatites and compounds with related structures are in the focus of the current research activities. Additionally, some attention has been paid to compounds with xenotime, kosnarite and florencite structure.

\section{1 $\mathrm{LnPO}_{4}$ phosphates: monazite and xenotime}

The ortho-phosphates of lighter and larger lanthanides $\left(L n \mathrm{PO}_{4} ; L n=\mathrm{La}-\mathrm{Gd}\right)$ crystallise in the monoclinic 
Table 1: Overview about relevant phosphate waste forms.

\begin{tabular}{|c|c|c|c|c|}
\hline Name & General formula & Crystal structure & Immobilised RN & Natural analogues \\
\hline Monazite & $\mathrm{LnPO}_{4}(\mathrm{Ln}=\mathrm{La}-\mathrm{Gd})$ & Monoclinic & $A n^{3+/ 4+}$ & Yes $_{\text {cryst. }}$ \\
\hline Xenotime & $\mathrm{LnPO}_{4}(\mathrm{Ln}=\mathrm{Tb}-\mathrm{Lu}, \mathrm{Sc} \& \mathrm{Y})$ & Tetragonal & $A n^{4+}$ & Yes \\
\hline Cheralite (brabantite) & $\mathrm{CaAnPO}{ }_{4}$ & Monoclinic & $A n^{4+}$ & Yes $_{\text {met. }}$ \\
\hline Th-phosphate-diphosphate & $\beta-\mathrm{Th}_{4}\left(\mathrm{PO}_{4}\right)_{4} \mathrm{P}_{2} \mathrm{O}_{7}$ & Orthorhombic & $A n^{4+}$ & No \\
\hline Apatite & $M e^{\| 1}{ }_{10}\left(X^{N} O_{4}\right)_{6} Y_{6}$ & Hexagonal & $\mathrm{Cs}^{+}, \mathrm{Sr}^{2+}, \mathrm{I}^{-} A n^{3+/ 4+}$ & Yes $_{\text {cryst. }}$ \\
\hline Britholite & $\mathrm{Ca}_{9} L n^{\prime \prime \prime \prime}{ }_{1-\mathrm{x}} A n_{\mathrm{x}}^{\mathrm{IV}}\left(\mathrm{PO}_{4}\right)_{5-\mathrm{x}}\left(\mathrm{SiO}_{4}\right)_{1+\mathrm{x}} \mathrm{F}_{2}$ & Hexagonal & $\mathrm{Cs}^{+}, \mathrm{Sr}^{2+}, \mathrm{I}^{-} A n^{3+/ 4+}$ & $\mathrm{Yes}_{\text {met. }}$ \\
\hline Kosnarite & $\mathrm{KZr}_{2}\left(\mathrm{PO}_{4}\right)_{3}$ & Trigonal & $A n^{3+/ 4+}$ & Yes \\
\hline Florencite & $\begin{array}{l}L^{\prime \prime \prime} \mathrm{Al}_{3}\left(\mathrm{PO}_{4}\right)_{2}(\mathrm{OH})_{6} \\
(\mathrm{Ln}=\text { mainly } \mathrm{Ce})\end{array}$ & Trigonal & $A n^{3+}$ & Yes \\
\hline
\end{tabular}

RN: radionuclides; cryst.: crystalline; met.: (often) metamict.

The indices at natural analogues point to the crystallinity of existing An-bearing natural analogues [32, 33].

monazite structure with space group $P 2 / n$ (Figure 1a). In contrast, those of heavier and smaller lanthanides $(\mathrm{Ln}=\mathrm{Tb}-\mathrm{Lu})$ adopt the zircon-type tetragonal structure of xenotime with the space group $14_{1} /$ amd (Figure 1b) [26, 35]. The limits between the monazite and xenotime structure for the lanthanides located in the middle of series is not strictly defined and seems to be strongly dependent on the synthesis procedures and environmental conditions. The actinides to be considered for immobilisation exhibit ionic radii comparable to the lighter lanthanides [36] and are known to form phosphates with a monazite structure. Therefore, monazite is the preferred crystal structure for the incorporation of trivalent minor actinides and $\mathrm{Pu}$.
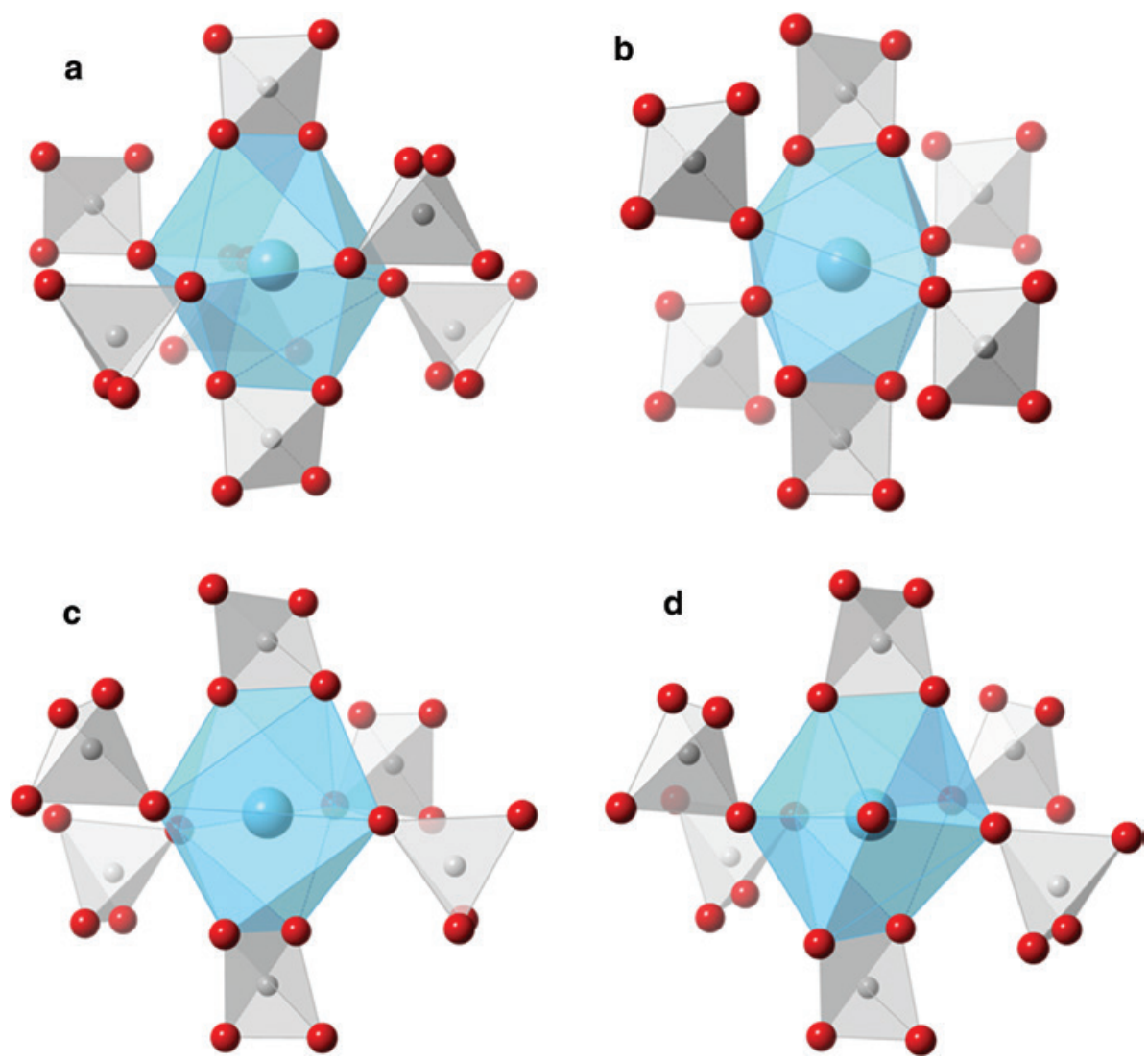

Figure 1: Local structural environment of the central atom in the monazite (A), xenotime (B) and rhabdophane structure (C and D). According to Mesbah et al. [34] the central atom in the hydrated rhabdophane structure exhibit both eight-fold (C) and nine-fold (D) coordination. Blue: central atom $(L n, A n)$ and $(L n, A n) \mathrm{O}_{9}$ polyhedron; red spheres: oxygen atoms; grey: phosphorus atoms and $\mathrm{PO}_{4}$ tetrahedra. 
In the last decades, the incorporation of minor actinides and $\mathrm{Pu}$ in natural and synthetic monazite-type orthophosphates has been subject to extensive investigations since monazites fulfill most of the selection criteria for suitable ceramic waste forms such as high achievable waste loading, high chemical and thermal durability, sufficient chemical flexibility and high radiation resistance [9, 11, 16-18, 20, 32, 37]. Monazite is the most abundant lanthanide phosphate found in nature [37-39] and their outstanding stability have been demonstrated by these natural analogues being exposed to geological events for several hundred million years [40]. Additionally, natural monazites can contain significant amounts of naturally occurring radioelements, such as tetravalent Th and $\mathrm{U}$ without suffering amorphisation from radiation damages $[37,41-43]$ or significant chemical weathering $[43,44]$.

In numerous studies, the structure and properties of pure monazite-type endmembers [45-50] and of mixed solid solutions containing mainly non-radioactive analogues of trivalent actinides [51-55] have been investigated. Single phase lanthanide phosphate solid solutions in the range $L n=\mathrm{La}-\mathrm{Gd}$ can be prepared after sintering (cf. [26, 51, 53-56]). In contrast, studies on actinide-bearing monazite materials are rather rare. As expected based on the surrogate studies, $\mathrm{Pu}-[57,58], \mathrm{Am}-[59-61], \mathrm{Cm}-[62-$ 64] as well as Cf-, Bk-, and Es-orthophosphates [65] were reported to crystallise in a monoclinic monazite structure because the ionic radii of these actinides fit into the range between $\mathrm{La}$ and $\mathrm{Gd}[36]$. The formation of $\mathrm{Pu}^{\mathrm{III}} \mathrm{PO}_{4}[61,66$, 67] monazite gained particular interest because it was synthesised in absence of additional reactants to reduce the oxidation state of $\mathrm{Pu}^{\mathrm{IV}}$ to $\mathrm{Pu}^{\mathrm{III}}$ during reaction. The formation of $\mathrm{Pu}^{\text {III }} \mathrm{PO}_{4}$ was confirmed by Popa et al. [68] by X-ray Absorption Near Edge Structure (XANES) spectroscopy measurements. Additionally, the thermal behaviour of $\mathrm{Pu}^{\text {III }} \mathrm{PO}_{4}$, such as lattice expansion and thermal decomposition during heat treatment was studied by Jardin et al. [69]. Moreover, XANES measurements by Begg et al. indicated the formation of $\mathrm{Np}^{\mathrm{III}} \mathrm{PO}_{4}[70]$.

Based on these results it can be concluded that the minor actinides and $\mathrm{Pu}$ can be immobilised in the structure of a monazite-type waste matrix. Actinide-bearing solid solutions with monazite structure were successfully prepared by the solid state synthesis route. Popa et al. [71], and Arinicheva et al. [72] as well as Zhang and Vance [73] reported the preparation of single phase $\mathrm{La}_{1-\mathrm{x}} \mathrm{Pu}_{\mathrm{x}} \mathrm{PO}_{4}$ solid solutions up to a Pu-content of $15 \mathrm{~mol} \%$. The oxidation state $+\mathrm{III}$ of Pu was confirmed by XANES $[68,72]$ and diffuse reflectance spectroscopy [73], respectively. For self-irradiation studies, $(\mathrm{La}, \mathrm{Pu}) \mathrm{PO}_{4}$ doped with ${ }^{238} \mathrm{Pu}$ was synthesised by a wet chemical method based on precipitation from aqueous nitrate solutions by Burakov et al. $[19,58]$.

Rhabdophane (monoclinic $L n \mathrm{PO}_{4} \cdot 0.667 \mathrm{H}_{2} \mathrm{O} ; \mathrm{Ln}=\mathrm{La}$ - Dy) is the hydrated form of $L n$-orthophosphate and plays an important role for the consideration of monazite-type ceramics for nuclear waste management applications. The interrelation between monazite- and rhabdophane-type phases is schematically represented in Figure 2. Rhabdophane is formed by using low temperature wet chemical methods such as precipitation to synthesise precursor materials for the subsequent fabrication of monazite-type waste matrices by sintering. The crystal structure of rhabdophane was first described by Mooney in the middle

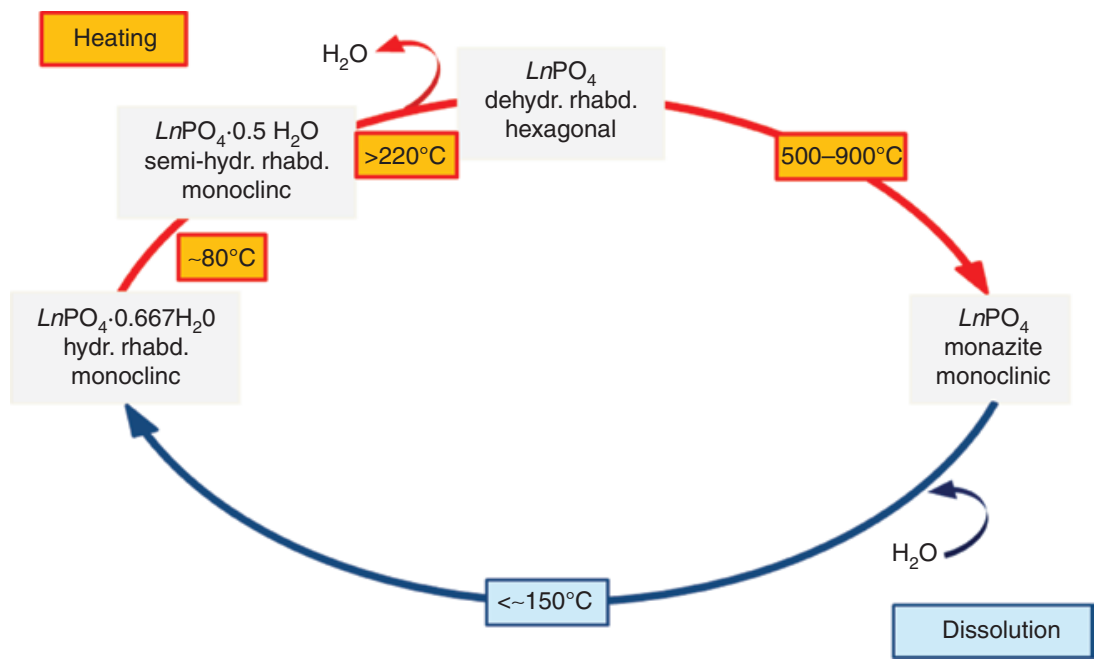

Figure 2: Schematic description of stability and interrelation of monazite- and rhabdophane-type lanthanide orthophosphates (Modified after Clavier at al. [74] considering new data from Mesbah et al. [34, 75]). 
of the last century to be tetragonal [76] assuming that the lanthanides are eight-fold coordinated by oxygen. Recently, an extensive reinvestigation of the crystal structure and the dehydration mechanism of rhabdophane during thermal treatment by Mesbah et al. [34, 75] using high resolution synchrotron X-ray diffraction allowed for a refined description of the rhabdophane structure. They found a monoclinic structure with a mixture of eightand nine-fold coordinated lanthanides (Figure 1c and d, respectively) and a water content of 0.667 water molecules per formula unit [34]. At $\sim 80^{\circ} \mathrm{C}$ the water molecules are partially evaporated forming semi-hydrated rhabdophane $\left(\mathrm{LnPO}_{4} \cdot 0.5 \mathrm{H}_{2} \mathrm{O}\right)$ with monoclinic structure. Above $220^{\circ} \mathrm{C}$ a complete dehydration was observed yielding a hexagonal structure of dehydrated rhabdophane [75]. Finally, the phase transition from rhabdophane to monazite between $500^{\circ} \mathrm{C}$ and $900^{\circ} \mathrm{C}$ occurs during thermal treatment [77]. Additionally, rhabdophane can form from monazite in aqueous environments at low temperature $\left(\mathrm{T}<\sim 150^{\circ} \mathrm{C}\right)$ [78]. The temperature of these phase transitions strongly depends on the chemical composition. Since the low temperature range can be expected in a deep geological repository in the long-term, the rhabdophane-type phase can occur as a potential neo-formed phase on the surface of monazite waste forms in contact with groundwater in a repository i.e. after failure of the waste canister. Hence, the rhabdophane phase is of particular interest concerning the application of monazite waste forms as it might control the radionuclide release from monazite-type ceramics due to very low solubility of secondary phases $[78,79]$.

The rhabdophane structure and water content were recently confirmed from data of a systematic study on the solubility of $L n \mathrm{PO}_{4} \cdot 0.667 \mathrm{H}_{2} \mathrm{O}(\mathrm{Ln}=\mathrm{La}-\mathrm{Dy})$ performed by Gausse et al. [79]. They reported a solubility range from $\log K_{s, 0}^{\circ}(298 K)=-25.6 \pm 0.8(\mathrm{Pr})$ to $-24.9 \pm 1.7(\mathrm{Eu})$ with a minimum from $\mathrm{Pr}$ to $\mathrm{Sm}$ which is in very good agreement with data of the associated monazite. The $\Delta_{f} H^{\circ}$ were determined to be between $-2151 \pm 13$ (La) and $-2130 \pm 12(\mathrm{Gd})$ $\mathrm{kJ} \cdot \mathrm{mol}^{-1}$ with an exception of $\mathrm{Eu}(-2057 \pm 9) \mathrm{kJ} \cdot \mathrm{mol}^{-1}$. Data estimated by simply adding the formation enthalpy of $0.667 \mathrm{H}_{2} \mathrm{O}$ molecules to the values of the monazite compositions [49] reveal similar results and trends.

The formation of rhabdophane and the phase transition to monazite is well described in the literature for several pure lanthanide phosphates [51, 78-82] as well as for solid solutions [51, 55, 82]. However, information about phase transitions of $A n$-phosphates is rare. Rai et al. [59] discussed the solubility of $\mathrm{AmPO}_{4} \cdot \mathrm{xH}_{2} \mathrm{O}$ and a phase transition at higher temperatures. Keller and Walter [63] reported a monoclinic $\mathrm{AmPO}_{4}$ phase after thermal treatment at $>200^{\circ} \mathrm{C}$. Finally, only Bjorklund [57] published an experimentally derived phase transition of Pu-rhabdophane to Pu-monazite after thermal treatment at $950^{\circ} \mathrm{C}$.

\subsection{Cheralite and yavapaiite}

The high flexibility of the monazite structure allows also for the incorporation of tetravalent actinides such as $\mathrm{Th}^{4+}$. In natural and synthetic monazites [83] a limited amount i.e. a few weight percent, of tetravalent actinides can be incorporated by the direct replacement of trivalent lanthanides associated with the formation of vacancies within the crystal structure [84].

A more efficient mechanism to incorporate larger amounts of tetravalent actinides offers the simultaneous coupled substitution with divalent cations (2 $\left.L n^{\mathrm{III}} \leftrightarrow M e^{\mathrm{II}}+M e^{\mathrm{IV}}\right)$ to form double phosphates with the general formula $M e^{\amalg I} M e^{\mathrm{IV}}\left(\mathrm{PO}_{4}\right)_{2}$ [85]. The coupled substitution avoids the formation of vacancies because it fulfills the conditions of the electroneutrality principle [86]. Depending on the cationic radii, two main structural families can be distinguished (Figure 3): the yavapaiitefamily, e.g. $\mathrm{Ba} A n\left(\mathrm{PO}_{4}\right)_{2}\left(A n=\mathrm{Np}^{\mathrm{IV}}\right.$ and $\left.\mathrm{Th}^{\mathrm{IV}}\right)[87,88]$ with a monoclinic $\mathrm{KFe}\left(\mathrm{SO}_{4}\right)_{2}$ structure $(\mathrm{C} 2 / \mathrm{m})$ [89], and the cheralite structure (formerly known as brabantite [90]), e.g. $\mathrm{Ca} A n\left(\mathrm{PO}_{4}\right)_{2}\left(A n=\mathrm{Th}^{\mathrm{IV}}, \mathrm{U}^{\mathrm{IV}}, \mathrm{Np}^{\mathrm{IV}}\right.$ and $\left.\mathrm{Pu}^{\mathrm{IV}}\right)$ that is isotypic with monazite [91].

Based on data available in the literature, Bregiroux et al. [85] recently discussed the stability fields of the yavapaiite/cheralite structures in the $M e^{\mathrm{II}} M e^{\mathrm{IV}}\left(\mathrm{PO}_{4}\right)_{2}$ system. Figure 4 shows the relation between the structure of cheralite-type and yavapaiite-type compounds as a function of cationic radii.

Popa et al. [92] investigated the structure of $\operatorname{SrNp}\left(\mathrm{PO}_{4}\right)_{2}$. They reported a layered structure that is characteristic for yavapaiite-type double phosphates and offered a new type of phosphate suitable for the incorporation of $\mathrm{Np}^{\mathrm{IV}}$.

According to Podor et al. [93], the formation of a cheralite-type structure is restricted by the mean radii of the di- and tetravalent cations [similar to monazitecompatible lanthanides ( $\mathrm{La}$ to $\mathrm{Gd}$ )] and their ratio $\left(\mathrm{r}\left(M e^{\mathrm{II}}\right) / \mathrm{r}\left(M e^{\mathrm{IV}}\right)\right)$. Due to these constraints all of the known cheralites are actinide-bearing compounds with $\mathrm{Ca}^{2+}$ as the only eligible divalent cation that is compatible with $\mathrm{Th}^{\mathrm{IV}}$, $\mathrm{U}^{\mathrm{IV}}[94-96], \mathrm{Np}^{\mathrm{IV}}[97,98]$ and to a smaller extent $\mathrm{Pu}^{\mathrm{IV}}$ [99].

$\mathrm{CaTh}\left(\mathrm{PO}_{4}\right)_{2}$ gained wide spread interest because of its ability to host tetravalent actinides such as $\mathrm{Np}^{\mathrm{IV}}$ and to a lesser extent $\mathrm{Pu}^{\mathrm{IV}}$ while keeping the distinct properties 

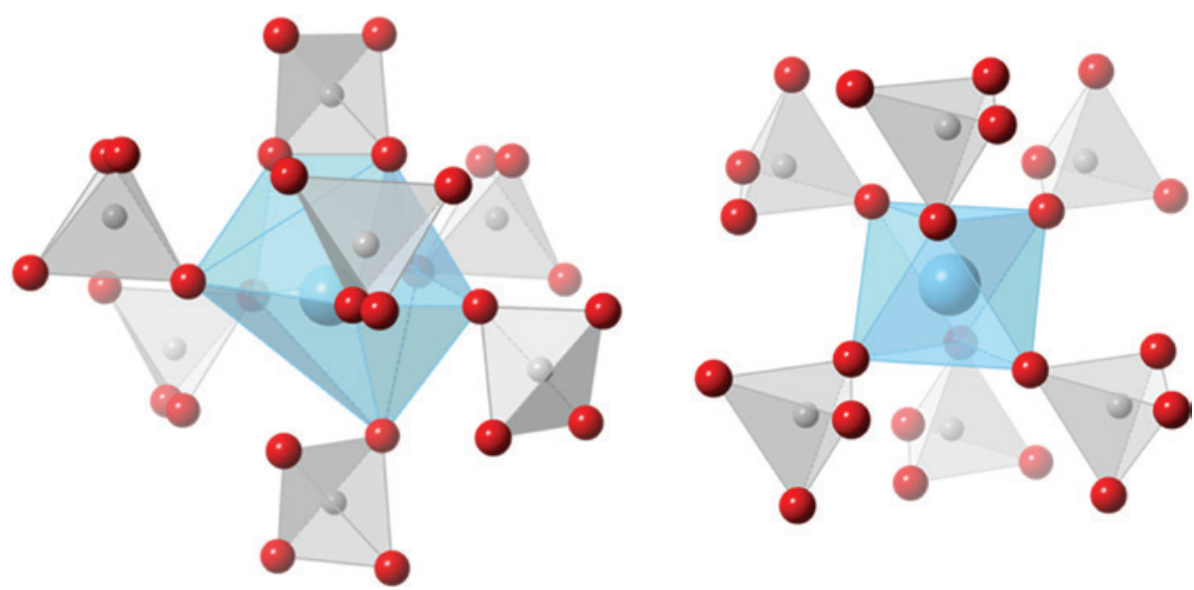

Figure 3: Local structural environment of the central atoms in the cheralite (left) and the yavapaiite structure (right). Blue: $\left(M e^{\prime \prime}, M e^{i v}\right)$ atom and $\left(M e^{\prime \prime}, M e^{i v}\right) \mathrm{O}_{\mathrm{x}}$ polyhedra; red spheres: oxygen atoms; grey: phosphorus atoms and $\mathrm{PO}_{4}$ tetrahedra.

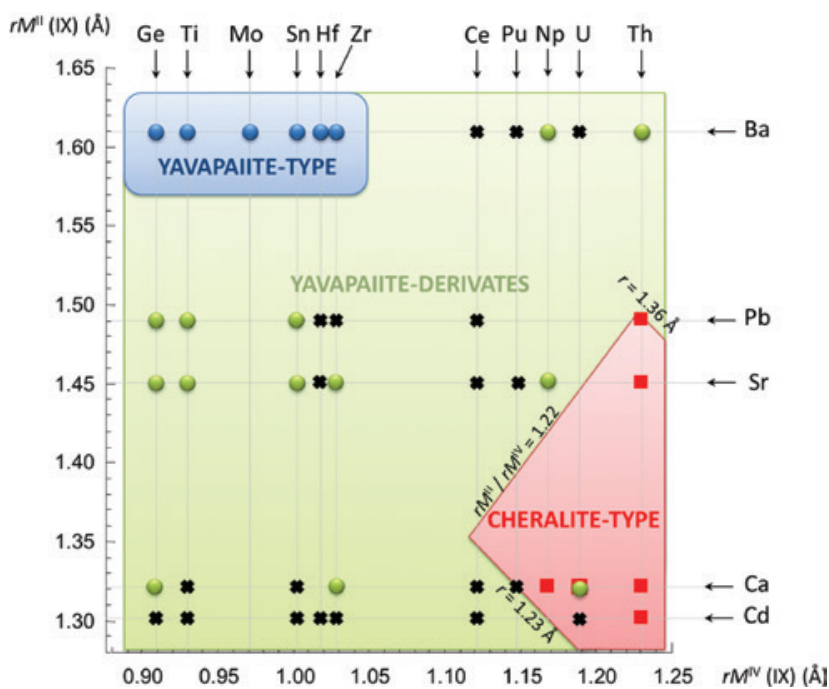

Figure 4: Stability fields of cheralite-type and yavapaiite-type compounds in dependence on chemical composition and ionic radii. With courtesy of D. Bregiroux, G. Wallez and K. Popa.

of monazite such as high aqueous durability [78, 100]. Terra et al. [101] and Podor et al. [93, 95] successfully prepared $\mathrm{Ca}_{0.5} \mathrm{Th}_{0.5} \mathrm{PO}_{4}$ and mixed actinide compounds, $\mathrm{Ca}_{0.5} \mathrm{Th}_{0.5-\mathrm{x}} \mathrm{U}_{\mathrm{x}} \mathrm{PO}_{4}$ with $0 \leq \mathrm{x} \leq 0.5$, respectively. Tabuteau et al. [97] reported the formation of $\mathrm{Ca}_{0.5} \mathrm{~Np}_{0.35} \mathrm{Pu}_{0.15} \mathrm{PO}_{4}$ by the simultaneous incorporation of tetravalent neptunium and plutonium. However, the successful synthesis of pure $\mathrm{Ca}_{0.5} \mathrm{Pu}^{\mathrm{IV}}{ }_{0.5} \mathrm{PO}_{4}$ or its non-radioactive analogue $\mathrm{Ca}_{0.5} \mathrm{Ce}_{0.5}^{\mathrm{IV}} \mathrm{PO}_{4}$ failed so far. Instead, the formation of mixed valence compounds such as $\mathrm{Ca}_{0.3}^{\mathrm{II}} \mathrm{Pu}^{\mathrm{III}}{ }_{0.4} \mathrm{Pu}^{\mathrm{IV}}{ }_{0.3} \mathrm{PO}_{4}$ [99] and $\mathrm{Ca}_{0.09} \mathrm{Pu}_{0.09} \mathrm{La}_{0.73} \mathrm{Th}_{0.09} \mathrm{PO}_{4}$ [102] was observed; most likely due to a partial reduction of $\mathrm{Pu}^{\mathrm{IV}}$ or $\mathrm{Ce}^{\mathrm{IV}}$ to the oxidation state of +III during thermal treatment in inert [103] as well as in oxidative conditions [99]. Moreover, the successful

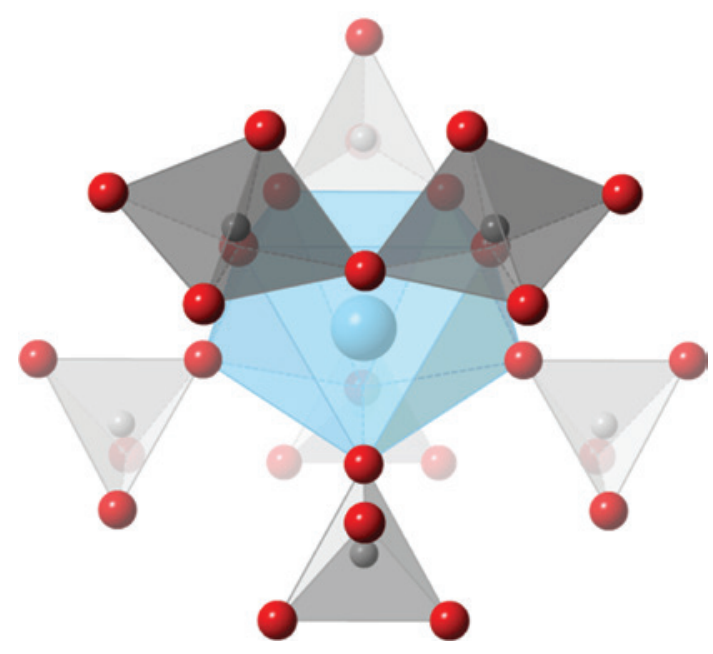

Figure 5: Local structural environment of Th in the thorium-phosphate-diphosphate structure. Blue: Th atom and $\mathrm{ThO}_{8}$ polyhedron; red spheres: oxygen atoms; grey: phosphorus atoms and $\mathrm{PO}_{4}$ tetrahedra.

synthesis of monazite-cheralite-type rhabdophanes $\left(L n_{1-2 x} \mathrm{Ca}_{\mathrm{x}} \mathrm{Th}_{\mathrm{x}} \mathrm{PO}_{4} \cdot \mathrm{nH}_{2} \mathrm{O} ; L n=\mathrm{Pr}\right.$ [104] and $\mathrm{Nd}$ [78]) was reported.

\subsection{Thorium-phosphate-diphosphate}

Another option to immobilise tetravalent actinides offers the thorium-phosphate-diphosphate phase, $\beta-\mathrm{Th}_{4}\left(\mathrm{PO}_{4}\right)_{4} \mathrm{P}_{2} \mathrm{O}_{7}(\beta-\mathrm{TPD})$. It crystallises in an orthorhombic system, $P b c m, Z=2$ [105] (Figure 5). Thorium can be substituted to a significant extent by $\mathrm{U}^{\mathrm{IV}}$ (47.6 wt.\%), $\mathrm{Np}^{\mathrm{IV}} \quad\left(33.2\right.$ wt.\%) and $\mathrm{Pu}^{\mathrm{IV}}(26.1$ wt.\%) forming $\beta-\mathrm{Th}_{4-\mathrm{x}} A n^{\mathrm{IV}}{ }_{\mathrm{x}}\left(\mathrm{PO}_{4}\right)_{4} \mathrm{P}_{2} \mathrm{O}_{7}(\beta-\mathrm{T} A n \mathrm{PD})[106-108]$. 
Analogous to the monazite-type phosphates, thorium phosphate hydrogenphosphate hydrates $\left(\mathrm{Th}_{2}\left(\mathrm{PO}_{4}\right)_{2}(\mathrm{HP}\right.$ $\mathrm{O}_{4} \cdot \mathrm{H}_{2} \mathrm{O}(\mathrm{TPHPH})$ ) were observed using low temperature wet chemical synthesis methods at $160^{\circ} \mathrm{C}[109,110]$ that converts to $\beta$-TPD under thermal treatment at $900^{\circ} \mathrm{C}$ to $1000^{\circ} \mathrm{C}[105,111]$. The very low solubility of TPHPH and the derived solid solutions allow for a quantitative precipitation of actinides from solution [110]. An actinidebearing TPHPH $\left(\mathrm{Th}_{2-\mathrm{x} / 2} A n^{\mathrm{IV}}{ }_{\mathrm{x} / 2}\left(\mathrm{PO}_{4}\right)_{2}\left(\mathrm{HPO}_{4}\right) \cdot \mathrm{H}_{2} \mathrm{O} ; A n^{\mathrm{IV}}=\mathrm{U}\right.$, $\mathrm{Np}, \mathrm{Pu}$ ) was reported by Dacheux et al. [112] for $\mathrm{x}=4$ for $\mathrm{U}^{\mathrm{IV}}, \mathrm{x}=0.8$ for $\mathrm{Np}^{\mathrm{IV}}$ and $\mathrm{x}=1.6$ for $\mathrm{Pu}^{\mathrm{IV}}$.

\subsection{Apatite and britholite}

Apatite-type phases crystallise in a hexagonal crystal structure with a $P 6_{3} / \mathrm{m}$ space group [113]. The general formula of apatite $\mathrm{Me}_{10}\left(\mathrm{XO}_{4}\right)_{6} \mathrm{Y}_{6}$ adumbrates the chemical flexibility of this mineral. $\mathrm{Me}$ represents divalent cations $\left(\mathrm{Me}=\mathrm{Ca}^{2+}, \mathrm{Sr}^{2+}, \mathrm{Ba}^{2+}, \mathrm{Pb}^{2+}\right.$ etc. $), X$ central pentavalent cations in trivalent anionic tetrahedrons $\left(\mathrm{XO}_{4}^{3-} ; \mathrm{X}=\mathrm{P}, \mathrm{V}\right.$ or As) replacable by tetravalent $\mathrm{SiO}_{4}{ }_{4-}^{4-}$ and divalent $\mathrm{CO}_{3}{ }^{2-}$ anions, and $Y$ monovalent anions like $\mathrm{F}^{-}, \mathrm{Cl}^{-}$and $\mathrm{OH}^{-}$ replaceable by $\mathrm{O}_{2}$ or oxygen vacancies.

Apatite-type ceramics were mainly investigated with respect to the immobilisation of $\mathrm{Cs}^{+}, \mathrm{Sr}^{2+}$ and $\mathrm{I}^{-}$isotopes. Yet, natural apatites, particularly from the Oklo site, contain tetravalent actinides (up to $100 \mathrm{ppm} \mathrm{Th}^{\mathrm{IV}}$ and

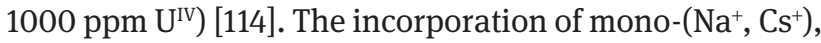
tri-( $\left.\mathrm{Al}^{3+}, \mathrm{Ln}^{3+}, \mathrm{An}^{3+}\right)$ and tetravalent $\left(\mathrm{Th}^{4+}, \mathrm{U}^{4+}, \mathrm{Pu}^{4+}\right)$ ions can be realised by a coupled substitution on the $M e$ and the $\mathrm{XO}_{4}$ sites $\left[\mathrm{Ca}^{2+}, \mathrm{PO}_{4}{ }^{3-}\right] \leftrightarrow\left[\mathrm{Ln}^{3+}, \mathrm{SiO}_{4}^{4-}\right]$ in order to satisfy the electroneutrality principle. Boyer et al. [113] showed that the incorporation of $\mathrm{Nd}^{3+}$ by coupled substitution of Ca by Nd and simultaneously of phosphate groups by silicate groups results in the formation of Nd-britholite that crystallises in the same symmetry within the same space group as apatite (Figure 6).

The incorporation of tetravalent actinides is achieved by an additional coupled substitution: $\left[\mathrm{Ln}^{3+}\right.$, $\left.\mathrm{PO}_{4}^{3-}\right] \leftrightarrow\left[\mathrm{An}^{4+}, \mathrm{SiO}_{4}^{4-}\right]$ forming britholites with a general formula $\mathrm{Ca}_{9} \mathrm{Nd}_{1-\mathrm{x}} A n_{\mathrm{x}}^{\mathrm{IV}}\left(\mathrm{PO}_{4}\right)_{5-\mathrm{x}}\left(\mathrm{SiO}_{4}\right)_{1+\mathrm{x}} \mathrm{F}_{2}$ with $A n^{\mathrm{IV}}=\mathrm{Th}$ and $\mathrm{U}[101,115,116]$ or a calcium-thorium silicate apatite [117]. As shown in Figure 6 the britholite structure features two different Ca-sites. The first Ca-site (Figure 6, left) is surrounded by nine oxygen atoms while the second $\mathrm{Ca}$-site (Figure 6, right) is seven-fold coordinated by six oxygen atoms and one fluorine atom. Experimental and modeling studies confirmed that lanthanides and $\mathrm{Pu}^{\mathrm{III}}$ are preferentially incorporated in the Ca-I site [118-120]. Vance et al. [121] reported the incorporation of $\mathrm{Pu}^{\mathrm{III}}$ in an excluslusively silicate-bearing britholite $\left(\mathrm{Ca}_{2} \mathrm{Gd}_{8-\mathrm{x}} \mathrm{Pu}_{\mathrm{x}}\left(\mathrm{SiO}_{4}\right)_{6} \mathrm{O}_{2}\right.$ in a reducing environment.

\subsection{Others}

Kosnarite and florencite have not been extensively investigated compared to other phosphate phases so far and will only be briefly addressed here. Kosnarite can be described by the general formula $M e^{\mathrm{I}} \mathrm{Me}^{\mathrm{IV}}\left(\mathrm{PO}_{4}\right)_{3}$ (Figure 7, left). Natural kosnarite $\left(\mathrm{KZr}_{2} \mathrm{PO}_{4}\right)$ crystallises in a trigonal (rhombohedral) crystal structure [122]. Synthetic kosnarite and its structural flexibility have been investigated by
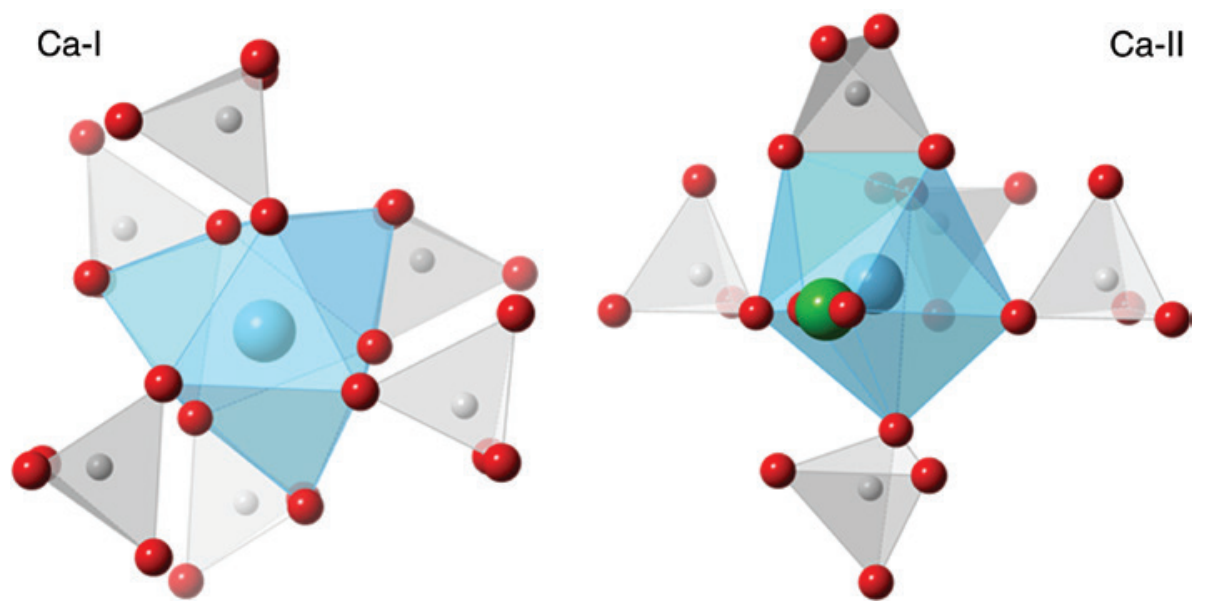

Figure 6: Local structural environment of two different $\mathrm{Ca}$ sites in the britholite structure. Blue: central atoms $(\mathrm{Ca}, L n)$ and $(\mathrm{Ca}, L n) \mathrm{O}_{6}$ polyhedra; red spheres: oxygen atoms; grey: phosphorus atoms and $\left(\mathrm{PO}_{4}, \mathrm{SiO}_{4}\right)$ tetrahedra; green: fluorine atom (possibly substituted by oxygen atoms). 

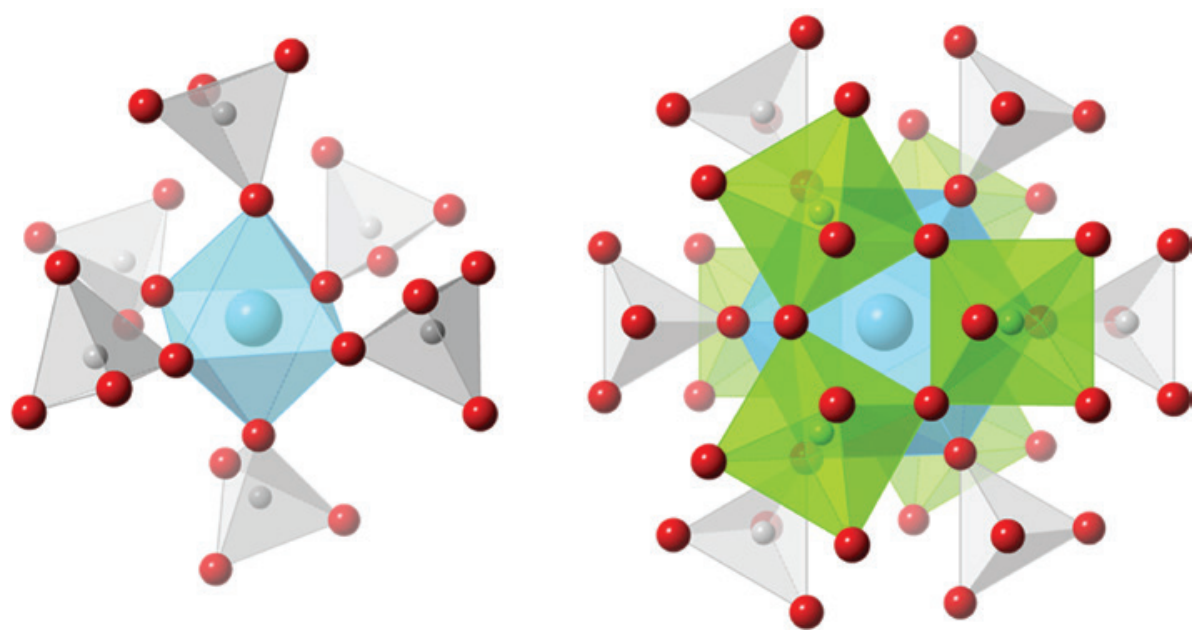

Figure 7: Local structural environment of the central atoms in the kosnarite (left) and florencite (right) structure. Blue: central atoms and $\left(M e^{!}, M e^{i v}\right) \mathrm{O}_{6}$ octahedron (kosnarite) and $\left(\mathrm{Ln}^{\prime \prime \prime} / \mathrm{An}^{\mathrm{II}}\right) \mathrm{O}_{12}$ polyhedron (florencite); red spheres: oxygen atoms; grey: phosphorus atoms and $\mathrm{PO}{ }_{4}$ tetrahedra; green: $\mathrm{AlO}_{6}$ octahedra.

Orlova et al. [123] to incorporate tetravalent actinides such as $\mathrm{Th}, \mathrm{U}^{\mathrm{IV}}, \mathrm{Np}^{\mathrm{IV}}$ and $\mathrm{Pu}^{\mathrm{IV}}$.

Florencite is a hydrous $\mathrm{Ln}$-Al-phosphate mineral $\left(\mathrm{Ln}^{3+}\right.$ $\left.\mathrm{Al}_{3}\left(\mathrm{PO}_{4}\right)_{2}(\mathrm{OH})_{6}\right)$ that mainly contains $\mathrm{Ce}^{3+}$ and occasionally $\mathrm{La}^{3+}$ and $\mathrm{Nd}^{3+}$ and crystallises in a trigonal (rhombohedral) crystal structure [124, 125] (Figure 7, right). Its crystal structure allows for the incorporation of trivalent actinides by a direct substitution of the lanthanides.

\section{Fabrication of phosphate waste forms}

The long-term stability of phosphate ceramic waste forms under conditions relevant to (geological) disposal is determined by a complex interrelation between its crystal structure, microstructure and properties. Synthesis and fabrication methods influence the phase purity and homogeneity of phosphate solid solutions as well as their microstructure. At the same time, crystal structure and microstructure significantly impact physico-chemical properties of ceramic materials including thermal conductivity, aqueous durability and resistance to radiation damage.

\subsection{Synthesis}

Ln-phosphate materials can be synthesised by several chemical processes [37, 126, 127]. The conventional solid state reaction implies the reaction between solid lanthanide-compounds, mainly $\mathrm{Ln}$-oxides and phosphorus $\left(\mathrm{NH}_{4} \mathrm{H}_{2} \mathrm{PO}_{4}\right)$ precursors $[46,99,116,128]$. In order to prepare pure and highly crystalline phosphate materials, lanthanide oxides are intensively mixed with a slight excess of the phosphate precursor and thermally treated at temperatures above $700^{\circ} \mathrm{C}$ depending on the material and composition [102]. In spite of the flexibility of the solid state route, the wet-chemical methods such as precipitation [51, 129, 130] and hydrothermal synthesis [131] offer some advantages over the solid state method. They yield highly homogeneous products with high specific surface areas and a tunable morphology. Moreover, they offer opportunities for the safe handling of radioactive materials during synthesis due to minimisation of contamination risks. A real waste form, e.g. a monazite-type phosphate can be assumed to belong at least to a ternary system comprising: (i) the main cation of the host material $\left(L n^{3+}\right)$, (ii) the immobilised actinide (e.g. $\left.A n^{3+}\right)$ and (iii) a neutron absorber for criticality reasons (e.g. $\mathrm{Gd}^{3+}$ ). This consideration defines the need of a detailed investigation of synthesis methods, structure and properties of $L n \mathrm{PO}_{4}$ solid solutions. All synthesis routes described above are suitable for the preparation of single phase solid solutions.

Ideally, the performance of specific waste forms developed for actinide immobilisation under conditions relevant for geological disposal should be evaluated with actinides-bearing materials. However, the use of radioactive elements in experimental development and testing for nuclear waste forms is costly, requires a high level of safety measures and is restricted to specialised laboratories. Therefore, inactive surrogates for the radioactive 
Table 2: Criteria for selection of surrogates for $\mathrm{Pu}^{+3 /+4}$ and $\mathrm{Am}^{+3}$.

\begin{tabular}{|c|c|c|c|c|c|}
\hline \multirow[t]{2}{*}{ Element } & \multirow[t]{2}{*}{$\begin{array}{l}\text { Valence } \\
\text { state }\end{array}$} & \multirow[t]{2}{*}{$\begin{array}{l}\text { Electronic } \\
\text { configuration }\end{array}$} & \multicolumn{2}{|c|}{$\begin{array}{r}\text { Ionic radius } \\
\text { [pm] [36] }\end{array}$} & \multirow[t]{2}{*}{$\begin{array}{l}\text { Redox potential } \\
\text { [V] [133] }\end{array}$} \\
\hline & & & [CN6] & [CN8] & \\
\hline \multirow[t]{2}{*}{$\mathrm{Pu}$} & (III) & {$[R n] 5 f^{5}$} & 100 & & $\mathrm{Pu}^{4+}+\mathrm{e}^{-} \leftrightarrow \mathrm{Pu}^{3+}$ \\
\hline & (IV) & {$[R n] 5 f^{4}$} & 86 & 96 & 1.006 \\
\hline \multirow[t]{2}{*}{$\mathrm{Ce}$} & (III) & {$[\mathrm{Xe}] 4 \mathrm{f}^{1}$} & 101 & 114.3 & $\mathrm{Ce}^{4+}+\mathrm{e}^{-} \leftrightarrow \mathrm{Ce}^{3+}$ \\
\hline & (IV) & {$[\mathrm{Xe}]$} & 87 & 97 & 1.72 \\
\hline Th & (IV) & {$[\mathrm{Rn}]$} & 94 & 105 & \\
\hline $\mathrm{Nd}$ & (III) & {$[\mathrm{Xe}] 4 \mathrm{f}^{3}$} & 98.3 & 110.9 & \\
\hline $\mathrm{Am}$ & (III) & {$[R n] 5 f^{6}$} & 97.5 & 109 & \\
\hline $\mathrm{Eu}$ & (III) & {$[\mathrm{Xe}] 4 \mathrm{f}^{6}$} & 94.7 & 106.6 & \\
\hline $\mathrm{Sm}$ & (III) & {$[\mathrm{Xe}] 4 \mathrm{f}^{5}$} & 95.8 & 107.9 & \\
\hline
\end{tabular}

The redox potentials indicated are associated to aqueous solutions and only informative.

elements are employed in fundamental investigations and in initial steps of waste form development. The chemical behaviour (oxidation state, ionic radii and electronic configuration) of the selected surrogate has to be sufficiently similar to the radioelement of interest to provide meaningful insights into the chemical and physical behaviour of a waste form. For example, $\mathrm{Ce}^{+3 /+4}$ is often used as surrogate for $\mathrm{Pu}$ because it is the most useful redox-active Pu-surrogate (e.g. [132]), although substantial differences in the redox potential from $\mathrm{Pu}^{+3 /+4}$ have to be taken into account (cf. Table 2) [133]. Surrogates cannot mimic all chemical properties of the radioactive element of interest. Therefore, a multi-surrogate approach is advisable for waste form development. For the fission products ( $\mathrm{Cs}, \mathrm{Sr}$, I) stable isotopes of the respective elements can serve as surrogates.

\subsection{Densification of phosphate ceramics}

The fabrication of ceramic waste forms was historically one of the main drawbacks compared to waste glasses, because the melting points of ceramic materials often exceed $2000^{\circ} \mathrm{C}$. However, in the last two decades tremendous progress was made in fabrication methods of ceramic waste forms that can be expanded to the industrial scale [134]. Generally, waste forms can be fabricated by sintering, uniaxial hot pressing (HUPing), isostatic hotpressing (HIPing) and melting. In a cold crucible melter, some ceramics such as Synroc-C can be produced from a homogeneous melt at a temperature $\sim 1500^{\circ} \mathrm{C}$ [135-138]. However, some questions still have to be addressed about the volatility of some fission products. Moreover at slow cooling rates in the large volume of the canister, the ceramic waste form will tend to form large crystals. These crystals would adversely affect the mechanical strength and its resistance to crack as a response to $\alpha$-radiation from actinide immobilisation.

As one of the advanced ceramic processing methods, HIPing has been extensively studied [139]. It has many obvious advantages over conventional methods like sintering or melting for processing high-level radioactive wastes. These advantages include: (i) no notable emissions of volatile radionuclides in the high temperature consolidation step due to the closed processing system, (ii) less secondary waste and (iii) flexible processing conditions. Several industry-scale HIPing systems are currently being set up for the processing of actinide-rich radioactive wastes [134]. However, at HIPing conditions (high temperatures, up to $2000^{\circ} \mathrm{C}$ and high pressure, 100$200 \mathrm{MPa}$ ), the waste form and the stainless steel container may interact, this interaction has already been demonstrated to be non-detrimental for several types of ceramic waste forms [140-142].

The densification processes for the preparation of dense pellets were thoroughly investigated for phosphate matrices. It is a crucial part of the waste form fabrication process, since the morphology of the precursor [82], the sintering method [143] and the sintering protocol [144] govern the final microstructure and porosity of the waste form. Monazite pellets with a relative density exceeding $95 \%$ can be prepared by sintering using a typical temperature range of $1350-1500^{\circ} \mathrm{C}[45,145,146]$. Sintering at higher temperature was observed to result in the decomposition of the phosphate group [147]. Hot-pressing methods allow for lowering the sintering temperature by about $250-300^{\circ} \mathrm{C}$ at $30 \mathrm{MPa}$, yielding pellets with $98 \%$ relative density [143, 148-152]. Du et al. [153-155] achieved the same density ( $98 \%$ ) of La-monazite after $3 \mathrm{~min}$ of sintering at $1350^{\circ} \mathrm{C}$ (heating rate $100^{\circ} \mathrm{C} \cdot \mathrm{min}^{-1}$ ) at a pressure of 40 MPa using Spark Plasma Sintering (SPS).

The densification of monazite-cheralite solid solutions is a very sensitive procedure. These materials require several milling steps to increase the reactivity of the materials for the sintering process, and tend to decompose at higher temperatures. However, thorium-bearing samples can be produced at a relative density of $\sim 95 \%$ whereas uranium-bearing pellets did not exceed $80 \%$ relative density $[96,101,115]$. Popa et al. [156] recently reported the densification of $\mathrm{CaTh}\left(\mathrm{PO}_{4}\right)_{2}$ to pure and highly dense pellets (up to $96.5 \%$ relative density) utilising the SPS technique.

For $\beta$-TPD and $\beta$-TUPD pellets relative densities of $92-$ $95 \%$ were obtained after sintering for $5-30 \mathrm{~h}$ at $1250^{\circ} \mathrm{C}$, with sintering times mainly depending on the synthesis 
method. The lowest holding time $(5-10 \mathrm{~h})$ was observed for sintering starting from a low temperature TPHPH precursor $[157,158]$.

Nd-britholithe and Th-britholithe can be densified up to $97 \%$ relative density by sintering at $1475^{\circ} \mathrm{C}$ for $6 \mathrm{~h}$ [159] while the U-britholithe pellets do not exceed $85 \%$ relative density, similar to the monazite-cheralite system. Moreover, the sintered U-bearing britholites were always found to be polyphase due to the formation of calcium uranate at the surface of the pellets [116].

\section{Correlation between structure and properties}

Various systematic studies have been performed on phosphate solid solution series in order to investigate the effect of incorporating foreign ions on the solid solution's stability. For numerous monazite-type ceramics a linear dependency of the lattice parameters as a function of the foreign ion content according to Vegard's law has been demonstrated. Examples include: (La, $\mathrm{Pr}) \mathrm{PO}_{4}[160]$; $(\mathrm{La}, \mathrm{Ce}) \mathrm{PO}_{4}$ [161, 162]; (La,Eu) $\mathrm{PO}_{4}[55] ;(\mathrm{La}, \mathrm{Gd}) \mathrm{PO}_{4}[51,54] ;(\mathrm{Ce}, \mathrm{Pr}) \mathrm{PO}_{4}$ [56]; (Ce,Sm) $\mathrm{PO}_{4}$ [163]; (Ce,Eu) $\mathrm{PO}_{4}$ [164], and (Ce,Gd)PO [165]. Hence, the structural features of the solid solutions are directly linked to the average ionic radius. The effect of ion size was systematically studied by short range order investigations (Raman and IR) on phosphate endmembers [48, 50, 166-168].

Recently, various properties of some monazite solid solutions have been systematically investigated. The results showed that physical properties such as Vicker's hardness, fracture toughness [55], Young's modulus and heat capacity [169] depend linearly on the average ionic radius of the cations in the solid solutions. Moreover, the heat capacity was comprehensively computed using density functional perturbation theory (DFT) [170]. It was shown that in DFT calculations both the lattice vibrations as well as the thermal excitations of $f$-electrons have to be considered to reproduce the experimental data on the heat capacity of monazites. Here, a direct correlation between the tendencies of some structural features (linear trend of lattice parameter) and specific properties (linear trend of heat capacity) can be observed. In contrast, some other properties such as enthalpy of formation and aqueous durability are not linearly dependent on the ion size. These and other effects can be elucidated with a combination of experimental and modeling approaches, a research strategy that has been significantly advanced in the last years.

\section{Progress in atomistic modeling of actinide-bearing phosphate waste forms}

Because of the popularity of computer simulation techniques related to the steady increase in the availability of computational power and the increasing complexity and capability of software [171] phosphate materials for actinide immobilisation have also been extensively investigated by atomistic modeling methods, including ab initio methods. The advantage of this approach is the characterisation of materials on the atomic scale, including their ionic and electronic structures. These "virtual experiments" are also not affected by the radiotoxicity and thus even actinide-containing materials can be effectively modeled. Various authors used density functional theory (DFT) for ab initio simulations of phosphates proving that "virtual experiments" can efficiently complement experimental efforts and substantially improve the knowledge gain on these materials.

Because $f$-elements are computationally challenging for DFT methods (strong correlation between $f$-electrons), $L n, A n$-phosphates have been used as test materials to improve the accuracy of computational methodologies. Blanca-Romero et al. [172] and Beridze et al. [173] found that the DFT $+U$ method, with the PBEsol exchange-correlation functional [174] and the Hubbard $U$ parameter derived $a b$ initio using the linear response method [175], results in excellent prediction of the structural parameters of monazites as illustrated in Figure 8. Moreover, the formation enthalpies of monazite- and xenotime-type ceramics were computed that could not be achieved with regular DFT calculations [176-178].

The elastic properties of lanthanide orthophosphates at ambient and high pressure were addressed in various computational studies of monazite- [179-182] and xenotime-type [183, 184] ceramics. Kowalski et al. [185] computed the variation of Young's modulus along the $\mathrm{La}_{1-\mathrm{x}} \mathrm{Eu}_{\mathrm{x}} \mathrm{PO}_{4}$ solid solution, complementing and interpreting relevant experimental studies [169]. It was also found that the elastic moduli increase with pressure, which also affects the elastic anisotropy [181, 184]. The computed elastic moduli were used to derive the thermal conductivities of phosphates [179, 183]. The results show relatively good agreement with measurements, which helps in explaining the difference (factor of $\sim 4$ ) in the thermal conductivities of monazite and xenotime. Similar computational methods were also applied to study the pressureinduced phase transition from xenotime to monazite in $\mathrm{TbPO}_{4}$ [186], $\mathrm{TmPO}_{4}$ [187]. Shein et al. [188] reported an 


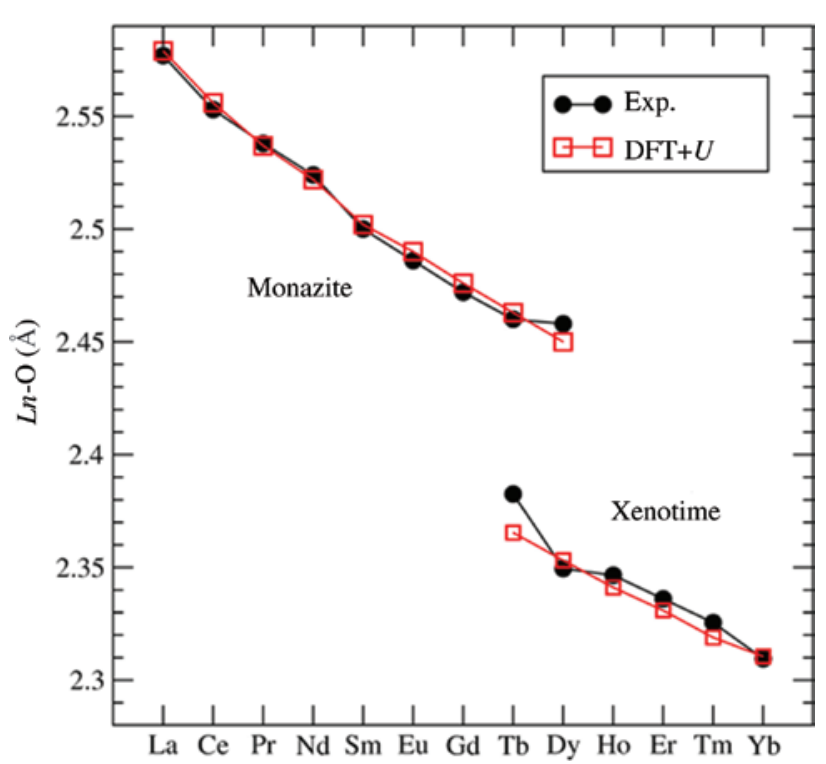

Figure 8: The $L n-0$ bond length in monazite- and xenotime-type $L n \mathrm{PO}_{4}$ computed by the DFT $+U$ method using Hubbard $U$ parameters computed $a b$ initio with the linear response method of Cococcioni and de Gironcoli $[173,175]$. The experimental data were obtained from different sources referenced in Beridze et al. [173].

increase of transition pressure of $\mathrm{Y}_{1-\mathrm{x}} \mathrm{La}_{\mathrm{x}} \mathrm{PO}_{4}(\mathrm{x}=0.0625$ and 0.125) compounds with increasing lanthanum content.

As mentioned in the preceding section, the systematic calculations of heat capacities of monazite- [170, 179] and xenotime-type [183] compounds allowed for the explanation of a quasi-like variation of the specific heat capacity along the lanthanide series as an effect of the thermal excitation of $f$-electrons (Schottky anomaly). The quality of these studies was demonstrated by an excellent match of the predictions to recent measurements of the heat capacity of $\mathrm{PrPO}_{4}$ monazite $[170,189]$ and the variation of heat capacities in $\mathrm{La}_{1-\mathrm{x}} \mathrm{Eu}_{\mathrm{x}} \mathrm{PO}_{4}$ solid solutions $[169,185]$. An important thermodynamic-driven aspect of the phosphates as potential nuclear waste form is the stability of monazite- and xenotime-type solid solutions against the formation of a miscibility gap with the related computational studies discussed in Section 6.1. Recently, molecular dynamics simulations of melting and radiation damage were conducted applying force-field methods using interaction potentials that are currently being developed for this class of materials [190-192]. This topic is briefly discussed in Section 6.2.

Atomistic simulations have been found useful for the interpretation of the broadening of the laser fluorescence peak of Eu doped (La,Gd)-monazite-type solid solutions. Based on the simulation results, Huittinen et al. [193] were able to explain the maximum broadening of the profiles observed for the intermediate solution compositions as the effect of distribution of the $\mathrm{Eu}-\mathrm{O}$ bond lengths in the Eu-doped homogeneous (La,Gd)-solid solutions. This research provides a solid argument for the homogeneity of the solid solution. Ab initio methods were also used to investigate the point defect properties in $\mathrm{YPO}_{4}$ xenotime [194] and the anisotropy in proton diffusion in xenotimetype $\mathrm{DyPO}_{4}[195]$.

This outlined menagerie of atomistic modeling studies on potential phosphate waste matrices shows the increasing popularity of these methods in research on waste-related nuclear materials. The authors expect this trend to hold in the future and that computer-aided "virtual experiments" will significantly complement the experimental efforts providing atomic-scale information that is useful for the characterisation of these materials.

\section{Long-term stability of phosphate ceramic waste forms}

In general, an application of ceramic materials as nuclear waste forms requires a refined understanding of the longterm behaviour of these materials under repository relevant conditions. It includes a description and prediction of the waste form stability over very long time scales on the basis of reliable data regarding chemical thermodynamics, chemical durability and radiation resilience of the waste form.

\subsection{Thermochemistry of phosphate ceramics}

The thermochemistry of phosphate waste forms, such as single phase solid solutions and their constituents provide the required information about the phosphates' stability, their tendency to destabilisation due to immiscibility and to phase separation over time.

Due to its technological significance, the thermodynamic properties of synthetic analogues of natural phosphate minerals such as monazite and xenotime are of general interest since the early 1950s. The data of these early studies are compiled in extensive tabulations [196198]. However, these data are often limited to endmembers and therefore provide only a limited view on the complete thermodynamical behaviour of series of phases or solid solutions in, for example, binary or ternary systems.

Thermodynamic data are experimentally accessible from calorimetric measurements [199-202] or can be derived from solubility data [79]. The calorimetry 
technique has been significantly developed and refined over the last decades [199, 200, 203-206] to expand the abilities to collect thermodynamic data from mg amounts of materials under different environmental conditions (e.g. oxygen atmosphere, argon atmosphere) and up to very high temperatures $\left(2000^{\circ} \mathrm{C}\right)[207]$.

The majority of thermochemical investigations were performed on pure $\mathrm{LnPO}_{4}$ endmembers [47, 49, 208-211], monazite-type solid solutions $[52,54,160]$ and to a lesser extent on monazite-cheralite-type solid solutions [212214]. Ushakov et al. [49] reported a roughly linear trend of the enthalpies of formation of $\mathrm{LnPO}_{4}$ endmembers consistent with the lanthanides contraction and the decrease of ionic binding energy in these materials which has been confirmed by $a b$ initio calculations $[172,176]$.

With respect to the use of phosphate materials as potential nuclear waste forms, the thermodynamic data of solid solutions are of particular interest since they will provide insight into the excess properties of materials that are close to the chemical composition of a realistic waste form after the incorporation of e.g. actinides and neutron absorbers into the crystal structure of the host matrix. Popa et al. [87] observed excess properties from enthalpy increment measurements of phosphate solid solutions $\left(\mathrm{La}_{1-\mathrm{x}} L n_{\mathrm{x}} \mathrm{PO}_{4} ; \mathrm{Ln}=\mathrm{Nd}, \mathrm{Eu}, \mathrm{Gd}\right)$ using high temperature calorimetry. The solid solutions of these phosphate series were found to be regular solid solutions and the observed non-ideal behaviour was ascertained to the mismatch of the size of substituting ions. Very recently the excess enthalpy of mixing of $\mathrm{La}_{1-\mathrm{x}} \mathrm{Ln}_{\mathrm{x}} \mathrm{PO}_{4}(\mathrm{Ln}=\mathrm{Pr}, \mathrm{Eu}, \mathrm{Gd})$ solid solutions were obtained from drop solution calorimetry $[54,160]$. The results in combination with spectroscopic $[54,193,215]$ and modeling studies $[182,216]$ confirm the mismatch of ionic radii as well as the lattice strain to be responsible for the excess properties of these monazitetype solid solutions. Geisler et al. [215], Neumeier et al. [54] and Huittinen et al. [193] observed a broadening in the Raman and laser fluorescence spectra of various monazite solid solutions. These observations are attributed to reflect lattice strain due to bond length distributions in the solid solutions.

An important aspect of phosphates as potential nuclear waste form is the thermodynamic stability of solid solutions against the formation of a miscibility gap. The miscibility gaps in the monazite-xenotime system were investigated by Mogilevsky and Boakye [217] applying a simple strain model, in which the excess enthalpies (described by the Margules interaction parameter $W$ ) were computed by considering the substitution of differently sized $L n$-cations and the related strain effects. Li et al. [216] performed $a b$ initio calculations of monazite-type solid solutions and found a quadratic relationship between the $W$ parameter and the volume difference of the endmembers, i.e. $W \sim \Delta \mathrm{V}^{2}$. In follow-up studies, Kowalski and Li [182] showed that this relationship is universal for any given pair of cations. By considering the strain energy associated with the incorporation of cations of different size, they found a simple relationship between the $W$ parameter and the Young`s modulus, $E,\left(W=E /(6 V) \Delta V^{2}\right)$, which explains the aforementioned quadratic relationship. The validity and importance of this derivation has been confirmed by thermochemical measurements of (La,Eu)- and (La,Gd)-solid solutions by Neumeier et al. [54]. One of the important outcomes of these studies is the prediction that $(\mathrm{La}, \mathrm{Pu})$-solid solutions are thermodynamically stable over the entire solid solution composition range and for temperatures above $300 \mathrm{~K}$ [216].

Only relatively few thermochemical data are available for actinide-bearing monazite solid solutions. Due to the radioactivity of such samples, experimental measurements can exclusively be performed in radiochemical laboratories and are therefore extremely costly. Thiriet et al. [218] and Beneš et al. [219] investigated the heat capacity of $\mathrm{PuPO}_{4}$ in the low (3-300 K) and high (530-1386 K) temperature range providing the temperature dependencies. Additionally, the derived standard entropy data for $\mathrm{PuPO}_{4}$ [218] allowed the evaluation of a semi-empirical method to estimate missing data for $\mathrm{AmPO}_{4}$ and $\mathrm{CmPO}_{4}$. Popa et al. [71] measured the low temperature heat capacity of a monazite-type $\mathrm{La}_{0.9} \mathrm{Pu}_{0.1} \mathrm{PO}_{4}$ solid solution and reported an antiferromagnetic effect due to $\mathrm{Pu}^{3+}$ in the solid solution system explaining anomaly effects in the low $\mathrm{T}$ range (4 K). Drop solution calorimetry measurements of the $\mathrm{CaTh}\left(\mathrm{PO}_{4}\right)_{2}$ endmember as well as the $L n_{1-2 \mathrm{x}} \mathrm{Ca}_{\mathrm{x}} \mathrm{Th}_{\mathrm{x}} \mathrm{PO}_{4}$ $(L n=\mathrm{La}, \mathrm{Ce}$ ) solid solution series were performed by Popa et al. [220] and Konings et al. [213] showing typical excess properties of regular solid solutions with a slight influence of the smaller $\mathrm{Th}^{4+}$ ions compared to the lanthanide ions. Recently, results of the heat capacity and standard molar enthalpies of formation of $\mathrm{La}_{1-2 \mathrm{x}} \mathrm{Ca}_{\mathrm{x}} \mathrm{Th}_{\mathrm{x}} \mathrm{PO}_{4}$ solid solutions were reported by Rawat et al. [214], indicating a stabilisation of the solid solution by the incorporation of $12.5 \mathrm{~mol} \%$ of $\mathrm{Th}^{4+}$ which is an appropriate waste load for the disposal of tetravalent actinides.

The calculations of excess properties of cheralitetype $\mathrm{CaThPO}_{4 \text { were }}$ e reported by Li et al. [190]. These effects were found to be much larger compared to directly substituted solid solutions, but consistent with the experimental studies of Konings et al. [213]. This enhancement is a consequence of the ordering in $M e^{\mathrm{II}} \mathrm{An}^{\mathrm{IV}} \mathrm{PO}_{4}$ compounds that is driven by the strong Coulomb effects arising when mixing cations of different charge. 


\subsection{Radiation damage effects in phosphate materials}

One of the key issues for crystalline ceramic waste forms concerns potential property changes in response to radiation-induced phase transformations due to the $\alpha$-decay of the incorporated actinides [220]. The radiation damage due to self-irradiation in ceramic waste forms is caused mainly by ballistic effects of the heavy recoiling nucleus ( $\sim 1500$ displacements per atom (dpa) over its $\sim 20 \mathrm{~nm}$ trajectory) and to a smaller extent by the emitted $\alpha$-particles due to ionisation ( $\sim 100$ dpa during its $\sim 20 \mu \mathrm{m}$ traverse) [221, 222].

The experimental investigation of radiation damages in ceramic materials can be performed in different ways. The most realistic method is the incorporation of shortlived radionuclides, such as ${ }^{244} \mathrm{Cm}\left(\mathrm{t}_{1 / 2}=18.1 \mathrm{a}\right)$ or ${ }^{238} \mathrm{Pu}$ $\left(\mathrm{t}_{1 / 2}=87.7 \mathrm{a}\right)[58,222-224]$ because the damaged zone is extended over the whole bulk material of the samples. However, due to the high radiotoxicity of the elements, these experiments are difficult to perform. They are costly and time-consuming, since time frames of several years are required until noticeable radiation damage is accumulated. A more flexible, practicable and widespread technique is the ion beam irradiation method [222, 225, 226]. This method allows for the handling of non-radioactive samples using surrogates and can be performed within a few hours. A disadvantage of the ion beam irradiation technique is the fact that a very thin damaged zone of few hundred $\mathrm{nm}$ to a few microns - depending on the energy of the ion - is produced. Extremely sensitive analytical techniques, e.g. Gracing Incidence X-Ray Diffraction (GIXRD) or Transmission Electron Microscopy (TEM), are needed to characterise the damaged zones in the samples with both methods beeing suitable to investigate radiation damage effects. However, self-irradiation studies based on doping with short-lived radionuclides (volumic irradiation) do not always induce the same damages and consequences in comparison to the more localised irradiation at the surface of the material due to external irradiation with heavy ions.

As a consequence of accumulated radiation damages, the crystal structure of the initially crystalline ceramics can undergo complete amorphisation. Monazitetype phosphates are known for their radiation resilience because natural monazite minerals do not exist in the metamict state although they can contain significant amount of $\alpha$-decaying actinides since several hundred millions of years [37, 38]. This effect is probably caused by self-annealing of the structure leading to recrystallised irradiated materials [41, 227]. The recrystallisation process predominantly depends on the critical temperature $\left(\mathrm{T}_{\mathrm{C}}\right)$ above which no amorphisation occurs. Meldrum et al. investigated critical amorphisation doses and $T_{C}$ for different pure lanthanide phosphates using $800 \mathrm{keV} \mathrm{Kr}^{2+}$ irradiation $[30,226,228,229]$. They found that $\mathrm{T}_{C}$ depends on the chemical composition, e.g. $\mathrm{T}_{C}\left(\mathrm{LaPO}_{4}\right)=333 \mathrm{~K}, \mathrm{~T}_{\mathrm{C}}$ $\left(\mathrm{EuPO}_{4}\right)=450 \mathrm{~K}$, and $\mathrm{T}_{\mathrm{C}}\left(\mathrm{GdPO}_{4}\right)=485 \mathrm{~K}$. Apatite shows the same tendency for recovery and recrystallisation [29]. The irradiation with $320 \mathrm{keV} \mathrm{Pb}$ - and $160 \mathrm{keV} H \mathrm{He}$-particles on Nd-britholite and fluoroapatite revealed that the phosphate groups mainly contribute to the annealing effects instead of the silicate groups [230].

Nasdala et al. [231] and Picot et al. [232] studied the behaviour of $\mathrm{CePO}_{4}$ under 1-7 MeV Au ion irradiation at total fluences of $0.6 \cdot 10^{13}-5.1 \cdot 10^{13}$ ions $\cdot \mathrm{cm}^{-2}$ showing an amorphisation at highest dose. Recently, Ji et al. [191] reported the amorphisation of a $\mathrm{La}_{0.2} \mathrm{Gd}_{0.8} \mathrm{PO}_{4}$ solid solution at a fluence of $\sim 10^{13}$ ions $\cdot \mathrm{cm}^{-2}$ using $100 \mathrm{MeV} \mathrm{Au}$ swift heavy ion irradiation at room temperature. These experiments were supported by simulations (SRIM/TRIM) [233-235] and atomistic modeling techniques [191] for the selection of best parameter for irradiation experiments and data interpretation.

The effect of matrix elements and dose rate on monazite amorphisation was demonstrated by Burakov et al. [58] and Bregiroux et al. [61], respectively, using the direct incorporation of relatively short-lived ${ }^{238} \mathrm{Pu}$ $\left(T_{1 / 2}=87.74\right.$ years $)$ and ${ }^{241} \mathrm{Am}\left(T_{1 / 2}=432.6\right.$ years). Burakov et al. observed a complete amorphisation of a ${ }^{238} \mathrm{Pu}$-doped $\mathrm{PuPO}_{4}$ monazite at a dose of $4.2 \cdot 10^{24} \alpha \cdot \mathrm{m}^{-3}$ while a ${ }^{238} \mathrm{Pu}$ doped $\mathrm{LaPO}_{4}$ monazite remained crystalline at a dose of $1.19 \cdot 10^{25} \alpha \cdot \mathrm{m}^{-3}$. The $\mathrm{PuPO}_{4}$ was found to amorphise completely at a lower dose compared to ${ }^{241} \mathrm{AmPO}_{4}$ [61].

The amorphisation of $\beta$-TPD and $\beta$-TUPD was observed under Kr-irradiation at $840 \mathrm{MeV}$ at a fluence of $10^{13}$ ions $\cdot \mathrm{cm}^{-2}$ and significantly depends on the electronic stopping power [236-238]. The critical threshold for electronic energy loss was determined to be 5 $\mathrm{MeV} \cdot \mu \mathrm{m}^{-1}$ [239]. In the nuclear stopping regime a complete amorphisation occurs at a critical dose of $0.2 \mathrm{dpa}$. The recrystallisation due to annealing to the initial crystalline structure was obtained at $973 \mathrm{~K}$. Additionally, TPD samples with high ${ }^{239} \mathrm{Pu}$ loading (up to $16.1 \mathrm{wt} \%$ ) were prepared which remained crystalline despite of the high dose they received [240].

In addition, there are increasing atomistic modeling activities on radiation damage processes in phosphates. Jolley et al. [192] performed ab initio simulations of melting and thermal expansion of $\mathrm{CePO}_{4}$. Ji et al. [191] and $\mathrm{Li}$ et al. [190] computed threshold displacement energies $\left(E_{d}\right)$ in $\mathrm{LaPO}_{4}$ and found the $E_{d}$ values for La that are by a factor of 
$\sim 2$ larger than the generic values usually assumed in the radiation damage simulations (e.g. SRIM code). Kowalski et al. [185] also found an interesting correlation between the $E_{d}$ values and the measured dissolution rates for $\mathrm{La}_{1-\mathrm{x}} \mathrm{Eu}_{\mathrm{x}} \mathrm{PO}_{4}$ solid solution [53].

\subsection{Aqueous durability of phosphate ceramics}

The waste containers emplaced in a deep geological repository for nuclear wastes built in crystalline rocks or clay formations will inevitably come into contact with ground water post-closure, after resaturation of the repository. Even in repositories in salt rocks, the presence of water cannot be completely ruled out for less probable scenarios, for example, an early failure of shaft seals and plugs. As a consequence, after container failure due to aqueous corrosion, the waste forms will come into contact with the near-field water, which can lead to a subsequent release of radionuclides as a result of waste form dissolution.

There are a number of relevant issues for the selection of a suitable waste matrix for the geological disposal of separated plutonium and/or minor actinides, if declared as waste, such as achievable waste loading, long-term durability, criticality control, as well as the maturity of the fabrication technology and safeguards (cf. [20]). Important issues with respect to the safety case for a geological disposal facility and the post-closure safety, which mostly determines disposability, comprise especially the aqueous durability of the waste form under the conditions encountered in the repository, and the rate at which radionuclides are released and can migrate into the repository near- and far-field. The potential for post-closure criticality excursions due to the accumulation of fissile materials leached from the waste matrices or due to a preferential leaching of neutron poisons is likewise related to the long-term dissolution behaviour of the waste forms under disposal conditions. The processes relevant to the longterm performance of the waste forms in a deep geological repository and their aqueous durability are controlled to a varying degree by thermodynamics and reaction kinetics and can be affected by the near-field hydro-(geo-)chemistry and the hydrodynamic regime [241].

Dissolution rates can be derived from standardised static laboratory dissolution tests, e.g. MCC-1 [242] and dynamic single-pass flow through (SPFT) tests [243]. All standardised static dissolution tests are typically shortterm laboratory tests, usually conducted for less than 1 month at drifting conditions, which occur according to the progress of the waste matrix dissolution. The dynamic
SPFT set-up prevents the progressive accumulation of reaction products which may affect element release rate. During the experiment, a continuous flow of fresh influent solution maintains constant, well defined chemical conditions within the flow-through reactor. The dissolution rate can be derived by quantification of the concentration of dissolved species in the leaching media in relation to the original inventory in the solid. Finally, the dissolution rate can be expressed as the elemental loss by mass normalised per unit surface area per unit time. In general, the dissolution rate significantly depends on $\mathrm{pH}$, temperature, chemical composition, and microstructure [244-247]. Additionally, the influence of phase transformations due to radiation damages, strength and species of ions in the water has to be considered.

Natural monazite from Madagascar was systematically investigated by Oelkers and Poitrasson [28] as a function of temperature from 50 to $230^{\circ} \mathrm{C}$ and $\mathrm{pH}$ from 1.5 to 10 . The dissolution rates were found to increase from $4.3 \cdot 10^{-17} \mathrm{~mol} \cdot \mathrm{cm}^{-2} \cdot \mathrm{s}^{-1}$ to $1.2 \cdot 10^{-14} \mathrm{~mol} \cdot \mathrm{cm}^{-2} \cdot \mathrm{s}^{-1}$ at $\mathrm{pH}$ 2 with increasing the temperature and to reach a minimum at near neutral $\mathrm{pH}$. An activation energy of $40 \mathrm{~kJ} \cdot \mathrm{mol}^{-1}$ was determined indicating a surface-controlled dissolution mechanism [248]. Du Fou de Kerdaniel [249] investigated the dissolution behaviour of $\mathrm{LnPO}_{4}$ monazite ( $L n=\mathrm{La}, \mathrm{Ce}, \mathrm{Nd}, \mathrm{Eu}$ and $\mathrm{Gd}$ ) in static experiments in $0.1 \mathrm{M}$ $\mathrm{HNO}_{3}$ at $90^{\circ} \mathrm{C}$ obtaining almost the same normalised dissolution rate $\left(1 \cdot 10^{-3} \mathrm{~g} \cdot \mathrm{m}^{-2} \cdot\right.$ day $^{-1}$ to $1.8 \cdot 10^{-3} \mathrm{~g} \cdot \mathrm{m}^{-2} \cdot$ day $\left.^{-1}\right)$ for all lanthanides consistent to the data determined by Oelkers and Poitrasson [28]. Sales et al. [250] and Ishida et al. [251] found in independent dissolution tests, a dissolution rate of synthetic monazite that is three orders of magnitude lower than that of borosilicate glasses. After 10 days, a rapid decrease of the normalised dissolution rate was observed due to saturation processes and precipitation of neo-formed phases. The constitution of the neoformed phase is mainly governed by the temperature and the ionic radius of the lanthanide elements as has been discovered by du Fou de Kerdaniel et al. (cf. Figure 1) [78]. They reported a reprecipitation at $150^{\circ} \mathrm{C}$ of lanthanide phosphates with monazite structure for the light lanthanides La and Ce and in contrast with rhabdophane structure for lanthanides from Nd to Dy. Taking into account other temperatures it can be concluded that at temperatures above $\sim 150^{\circ} \mathrm{C}$ the monazite phase will be stabilised while rhabdophane is the low-temperature phase of $\operatorname{LnPO}{ }_{4}$ in aqueous environments.

The dissolution rate of monazite-type solid solutions has been investigated for $\mathrm{La}_{1-\mathrm{x}} \mathrm{Gd}_{\mathrm{x}} \mathrm{PO}_{4}$ [51] in dependence of $\mathrm{pH}$ at $90^{\circ} \mathrm{C}$ in static dissolution experiments. The dissolution rate significantly decreases from $\mathrm{pH} 1_{\mathrm{HCl}}\left(3.8 \cdot 10^{-4}\right.$ 
$\left.\mathrm{g} \cdot \mathrm{m}^{-2} \cdot \mathrm{day}^{-1}\right)$ to $\mathrm{pH} 4_{\mathrm{HCl}}\left(4.8 \cdot 10^{-6} \mathrm{~g} \cdot \mathrm{m}^{-2} \cdot \mathrm{day}^{-1}\right)$. The same tendency was observed for $\mathrm{Ce}_{0.5} \mathrm{Pr}_{0.5} \mathrm{PO}_{4}[148]$. The dissolution rate varied between $\sim 10^{-3} \mathrm{~g} \cdot \mathrm{m}^{-2} \cdot$ day $^{-1}$ at $\mathrm{pH} 3$ and $\sim 10^{-7} \mathrm{~g} \cdot \mathrm{m}^{-2} \cdot$ day $^{-1}$ at $\mathrm{pH} 7$ with no significant change when increasing the temperature from $90^{\circ} \mathrm{C}$ to $200^{\circ} \mathrm{C}$ and no significant influence of the fabrication method i.e.either using conventional sintering or hot-pressing [143, 148]. Brandt et al. [53] investigated the dissolution behaviour of $\mathrm{La}_{1-\mathrm{x}} \mathrm{Eu}_{\mathrm{x}} \mathrm{PO}_{4}$ solid solutions in dynamic dissolution experiments at $\mathrm{pH} 2$ and $90^{\circ} \mathrm{C}$. They reported a normalised dissolution rate between $5 \cdot 10^{-5} \mathrm{~g} \cdot \mathrm{m}^{-2} \cdot$ day $^{-1}$ and $1.7 \cdot 10^{-3}$ $\mathrm{g} \cdot \mathrm{m}^{-2} \cdot$ day $^{-1}$ in dependence on the Eu content with a minimum at $\mathrm{X}_{\mathrm{EuPO} 4}=0.2$. Kowalski et al. [185] showed an interesting correlation between the measured dissolution rate for the $\mathrm{La}_{1-\mathrm{x}} \mathrm{Eu}_{\mathrm{x}} \mathrm{PO}_{4}$ solid solution [53] and the simulated threshold displacement energy. Both parameters show a minimum at $\mathrm{x} \sim 0.2$, which points towards a common origin of these phenomena. In the case of simulations the minimum is explained by the interplay of the two effects: (i) the lowering of the volume along the solution series and (ii) the weakening of the interaction between the $L n$ and $\mathrm{O}$ atoms with increase in $\mathrm{x}$, i.e. weaker interaction between $\mathrm{Eu}-\mathrm{O}$ than $\mathrm{La}-\mathrm{O}$. Moreover, experiments with ${ }^{241} \mathrm{Am}$-doped La-monazite in distilled water at $90^{\circ} \mathrm{C}$ revealed a normalised dissolution rate in a similar order of magnitude compared to synthetic monazite [60] and 300 times lower as reported for borosilicate glasses [252].

In contrast to the various studies on monazite, only few data are available concerning the aqueous durability of cheralite-type $\left(\mathrm{Ca}_{0.5}(\mathrm{U}, \mathrm{Th})_{0.5} \mathrm{PO}_{4}\right)$ materials and monazite-cheralite-type $\left(\operatorname{Ln}_{1-2 \mathrm{x}} \mathrm{Ca}_{\mathrm{x}}(\mathrm{U}, \mathrm{Th})_{\mathrm{x}} \mathrm{PO}_{4}\right)$ solid solutions. The dissolution behaviour of these phases was observed to depend significantly on the nature of the incorporated actinide. For instance, du Fou de Kerdaniel investigated the dissolution kinetics of various $\mathrm{La}_{0.4} \mathrm{Eu}_{0.1} \mathrm{Ca}_{0.25} A n_{0.25} \mathrm{PO}_{4}$ solid solutions $(A n=\mathrm{Th}, \mathrm{U})$ at $\mathrm{pH} 1$ and $90^{\circ} \mathrm{C}$ [78]. The dissolution of these materials was found to be highly incongruent with the dissolution rate of the Th-bearing solid solution $\left(1.7-4.3 \cdot 10^{-6} \mathrm{~g} \cdot \mathrm{m}^{-2} \mathrm{day}^{-1}\right)$ being two orders of magnitude lower compared to the U-bearing solid solution $\left(2-4 \cdot 10^{-4} \mathrm{~g} \cdot \mathrm{m}^{-2} \mathrm{day}^{-1}\right)$. The preferential release of $\mathrm{U}$ can probably be attributed to the oxidation of $\mathrm{U}^{\mathrm{IV}}$ to $\mathrm{U}^{\mathrm{vI}}$ $\left(\mathrm{UO}_{2}^{2+}\right)[51,78,253]$ while rapid saturation and precipitation of TPHPH occurred forming a passivating layer on the surface of the Th-bearing materials [241].

$\beta$-TPD and $\beta$-TAnPD solid solutions were found to be highly resistant $[240,254,255]$. The dissolution rates ranged from $1.2 \cdot 10^{-5} \mathrm{~g} \cdot \mathrm{m}^{-2} \cdot$ day $^{-1}$ at $\mathrm{pH} 1$ to $4.8 \cdot 10^{-8}$ $\mathrm{g} \cdot \mathrm{m}^{-2} \cdot$ day $^{-1}$ at $\mathrm{pH} 4$ at room temperature. The ${ }^{239} \mathrm{Pu}$ doped $\beta$-TPD dissolved with the same rate compared to the other samples which demonstrates the high resistance of these materials to radiation damages and radiolysis [240]. However, due to the very low solubility of the neo-formed phases [256], the saturation conditions were reached rather quickly. Although the irradiation of $\beta$-TPD lead to an increase of the dissolution rate by a factor of $10-100$, the material remains highly durable. It was found that inter alia the characteristics of the neo-formed phases are not influenced by the dissolution behaviour of the amorphised material [236-238]. In contrast, due to the increased dissolution kinetics the saturation conditions are reached more rapidly speeding up the formation of the protective layer thus hindering further dissolution [257].

Although britholite appears similar to the monazite-cheralite solid solutions from the chemical point of view, the dissolution behaviour differs significantly. Typically the normalised dissolution rates in $0.1 \mathrm{M} \mathrm{HNO}_{3}$ are $2.2 \cdot 10^{-5} \mathrm{~g} \cdot \mathrm{m}^{-2} \cdot$ day $^{-1}$ at $90^{\circ} \mathrm{C}$ for Th-cheralite and $2.1 \mathrm{~g} \cdot \mathrm{m}^{-2} \cdot$ day $^{-1}$ for Th-britholite at $25^{\circ} \mathrm{C}$. The dissolution behaviour of both systems have been systematically investigated to understand the difference from crystallographic aspect $[253,258]$ and demonstrated clearly that the chemical durability of $A n$-britholithes is significantly lower compared to that of $(L n, \mathrm{Ca}, A n)$-monazite-cheralite solid solutions. Complementary performed DFT-calculations revealed distinct differences in the cohesive energy of Ca in both structures that apparently cause such tremendous differences in the chemical durability of both matrices.

\section{Summary and conclusion}

In spite of several decades of international R\&D activities, the disposal of high level radioactive waste is one of the most demanding political, societal and scientific challenges of the $21^{\text {st }}$ century.

Among several other poly- and single-phase ceramics phosphate-based materials, for example monazite, monazite-cheralite, thorium-phosphates-diphosphates and britholite emerged as promising candidates for ceramic nuclear waste forms for specific radioactive waste streams containing Pu and MA, due to their specific physico-chemical properties. These include high structural flexibility allowing for significant waste loadings, high chemical durability, and high resilience against radiation damage. In particular, research activities focused on monazite-type and monazite-cheralite-type materials.

From a chemical and structural point of view, the phosphate family offers several options for the incorporation 
of cations and anions into the crystal structure by direct or coupled substitution. Dry and wet chemical methods have been developed to synthesise pure and homogeneous precursor materials. The wet chemistry methods are favourable over the solid state chemistry method due minimisation of contamination risk when handling radioactive materials. However, the incorporation of tetravalent actinides such as (Th, $\mathrm{U}, \mathrm{Np}$ ) is mainly performed by solid state chemistry. Particular interest has been paid to the incorporation of $\mathrm{Pu}$ due to its very complex redox-chemistry. Based on the synthesis routes available the most promising way to immobilise $\mathrm{Pu}$ is the incorporation into monazite or monazite-cheralite matrices in the oxidation state +III.

The methods to fabricate sintered specimens tremendously progressed in the last 20 years. New sintering methods, such as spark plasma sintering, offer new opportunities to immobilise volatile radionuclides and solidify materials very rapidly. Additionally, the maturity for the fabrication nuclear waste forms on the industrial scale has been demonstrated with HIPing most likely playing an important role.

Safe and reliable conditioning of nuclear waste streams requires a refined understanding of the long-term stability of the waste form under conditions relevant to geological disposal including the contact to aqueous environments in the long-term. This comprises aspects such as (i) the thermodynamic stability, (ii) the radiation resistance and (iii) the aqueous durability. All aspects have been addressed fully or partly for the discussed materials. For monazite it can be concluded that a chemically and thermodynamically stable waste form matrix can be formed by mixing lanthanides from $\mathrm{La}-\mathrm{Gd}$. The $\alpha$-decay of incorporated actinides does not have a significant influence on the dissolution rate of these materials. Similar aqueous durability can be attested to the monazite-cheralite system. However, the influence of radiation damages on the dissolution behaviour has not been investigated so far. The aqueous durability of $\beta$-TPD and $\beta$-TAnPD is more sensitive to radiation damage but still lower compared to borosilicate glasses. In contrast, the weak aqueous durability of britholite (up to 6 orders of magnitude lower than monazite) is unfavourable for a consideration as nuclear waste form.

The progress in the development of reliable and feasible atomistic modeling tools to compute the properties of $f$-elements like actinides and lanthanides has been very important to research in this field. This progress allows achieving results which are experimentally not accessible, for the interpretation of experimental results and for the pre-setting of parameter for advanced radiation damage experiments. A large number of examples demonstrated the benefit by the synergies of experiments and atomistic modeling.

The properties and stability of monazite and monazite-cheralite solid solutions as well as thorium-phosphates-diphosphates offer a large panel of varieties for the safe immobilisation of radionuclides from specific waste streams. In combination with available waste form fabrication techniques on industrial scale, these ceramic materials can be seen complementary to the immobilisation in borosilicate glasses, instead of competitive.

In perspective, as the long-term aqueous durability of monazite waste form is very sensitive to the near-field dissolution conditions (chemical composition of groundwater and EBS-concept) [259], experiments in groundwater-like media are needed in order to investigate the effect of various ions in the groundwater, e.g. phosphate and fluoride ions on dissolution kinetics and mechanisms under repository conditions.

Additionally, the effect of 'transmutation damage' caused by changes of ion size and valence that may occur during $\alpha$ - or $\beta$-decay of the immobilised radionuclides has not been investigated in detail so far. For instance, ${ }^{239} \mathrm{Pu}$ incorporated in a monazite matrix in the oxidation state $+\mathrm{III}$ will decay to ${ }^{235} \mathrm{U}$ that is probably in the $+\mathrm{IV}$ or $+\mathrm{VI}$ valence state, depending on the conditions in the nearfield, which is accompanied by a decrease in ionic radius of about $10 \%$.

More emphasis has to be put on experiments with actinide materials to include the very complex specific element chemistry of actinides, e.g. Pu. Additionally, these experiments will validate the knowledge collected from experiments using surrogates and models derived from atomistic modeling. The synergies between experimental and modeling research will be the key to develop a refined understanding of the complex processes in the repository on the atomic scale on the bases of reliable data.

Acknowledgements: This work was financially supported by the German Federal Ministry of Education and Research (BMBF); grant no.: 02NUK021A. The authors thank the JARA-HPC (Jülich Aachen Research Alliance, Section High Performance Computing) for computing time at the RWTH Aachen University and Forschungszentrum Jülich $\mathrm{GmbH}$ computing resources. Yulia Arinicheva thanks HITEC the Graduate School in Energy and Climate Research at the Forschungszentrum Jülich, Germany for financial support to her $\mathrm{PhD}$ thesis. Eike Langer from Forschungszentrum Jülich $\mathrm{GmbH}$ (IEK-6) is gratefully thanked for support of figures preparation. 


\section{References}

1. International Atomic Energy Agency (IAEA): Scientific and technical basis for the geological disposal of radioactive wastes. Technical Reports Series 413, Vienna, 80 pp. (2004).

2. Council of the European Union: COUNCIL DIRECTIVE 2011/70/ EURATOM of 19 July 2011 establishing a Community framework for the responsible and safe management of spent fuel and radioactive waste. Brussels, 56 pp. (2011).

3. Ahn, J., Apted, M. J.: Geological Repository Systems for Safe Disposal of Spent Nuclear Fuels and Radioactive Waste, Woodhead Publishing, Oxford, 792 pp. (2011).

4. USDOE. The Evaluation and Selection of Candidate High-Level Waste Forms, US Department of Energy Report DOE/TIC 11611, Savannah River Operations Office, Aiken, SC (1982).

5. Hench, L. L., Clark, D. E., Campbell, J.: High level waste immobilization forms. Nucl. Chem. Waste Manage. 5, 149 (1984).

6. Lutze, W., Ewing, R. C. (Eds.): Radioactive Waste Forms for the Future, North Holland, Amsterdam, Netherlands (1988).

7. Donald, I. W., Metcalfe, B. L., Taylor, R. N. J.: Review: the immobilisation of high level radioactive wastes using glasses and ceramics. J. Mater. Sci. 32, 5851 (1997).

8. Donald, I. W.: Waste Immobilization in Glass and Ceramic Based Hosts: Radioactive, Toxic and Hazardous Wastes, John Wiley \& Sons Ltd, Chichester, West Sussex, UK (2016).

9. Lumpkin, G. R.: Ceramic waste forms for actinides. Elements 2, 365 (2006).

10. Ewing, R. C.: Ceramic matrices for plutonium disposition. Prog. Nucl. Energy 49, 635 (2007).

11. Weber, W. J., Navrotsky, A., Stefanovsky, S., Vance, E., Vernaz, E.: Materials science of high-level nuclear waste immobilization. MRS Bull. 34, 46 (2009).

12. Vance, E. R., Perera, D. S., Moricca, S., Aly, Z., Begg, B. D.: Immobilisation of ${ }^{129}$ l by encapsulation in tin by hot-pressing at $200^{\circ}$ C. J. Nucl. Mater. 341, 93 (2005).

13. Carter, M. L., Gillen, A. L., Olufson, K., Vance, E. R.: HIPed tailored hollandite waste forms for the immobilization of radioactive Cs and Sr. J. Am. Ceram. Soc. 92, 1112 (2009).

14. Ringwood, A. E., Kesson, S. E., Ware, N. G., Hibberson, W., Major, A.: Immobilisation of high level nuclear reactor wastes in SYNROC. Nature 278, 219 (1979).

15. Ewing, R. C., Weber, W. J., Lian, J.: Nuclear waste disposal pyrochlore $\left(\mathrm{A}_{2} \mathrm{~B}_{2} \mathrm{O}_{7}\right)$ : nuclear wasteform for the immobilization of plutonium and "minor" actinides. Appl. Phys. Rev. 95, 5949 (2004).

16. Oelkers, E. H., Montel, J.-M.: Phosphates and nuclear waste storage. Elements 4, 113 (2008).

17. Dacheux, N., Clavier, N., Podor, R.: Versatile monazite: resolving geological records and solving challenges in materials science: monazite as a promising long-term radioactive waste matrix: benefits of high-structural flexibility and chemical durability. Am. Mineral. 98, 833 (2013).

18. Schlenz, H., Heuser, J., Neumann, A., Schmitz, S., Bosbach, D.: Monazite as a suitable actinide waste form. Z. Krist. 228, 113 (2013).

19. Burakov, B. E., Yagovkina, M. A., Zamoryanskaya, M. V., Petrova, M. A., Domracheva, Y. V., Kolesnikova, E. V., Nikolaeva, L. D., Garbuzov, V. M., Kitsay, A. A., Zirlin, V. A.: Behavior of actinide host-phases under self-irradiation: zircon, pyrochlore, monazite, and cubic zirconia doped with Pu-238. In: S. V. Krivovichev (Ed.),
Minerals as Advanced Materials, Springer, Berlin, Heidelberg (2008), p. 209.

20. Deissmann, G., Neumeier, S., Modolo, G., Bosbach, D.: Durability of potential plutonium wasteforms under repository conditions. Mineral. Mag. 76, 2911 (2012).

21. Carter, M. L., Stewart, M. W. A., Vance, E. R., Begg, B. D., Moricca, S., Tripp, J.: HIPed tailored ceramic waste forms for the immobilization of Cs, Sr, and Tc. In: Proceedings GLOBAL 2007, Boise, ID, USA (2007), p. 1022.

22. Angeli, F., McGlinn, P., Frugier, P.: Chemical durability of hollandite ceramic for conditioning cesium. J. Nucl. Mater. 380, 59 (2008).

23. Hartmann, T., Alaniz, A. J., Antonio, D. J.: Fabrication and properties of technetium-bearing pyrochlores and perovskites as potential waste forms. Procedia Chem. 7, 622 (2012).

24. Nenoff, T. M., Krumhansl, J. L., Gao, H. H., Rajan, A., McMahon, K.: lodine waste form summary report. Sandia National Laboratories Report SAND2007-6202, Albuquerque, New Mexico and Livermore, California (2007).

25. Gras, J. M., Do Quang, R., Masson, H., Lieven, T., Ferry, C., Poinssot, C., Debes, M., Delbecq, J. M.: Perspectives on the closed fuel cycle - implications for high-level waste matrices. J. Nucl. Mater. 362, 383 (2007).

26. Clavier, N., Podor, R., Dacheux, N.: Crystal chemistry of the monazite structure. J. Eur. Ceram. Soc. 31, 941 (2011).

27. Poitrasson, F., Oelkers, E., Schott, J., Montel, J.-M.: Experimental determination of synthetic $\mathrm{NdPO}_{4}$ monazite end-member solubility in water from $21^{\circ} \mathrm{C}$ to $300^{\circ} \mathrm{C}$ : implications for rare earth element mobility in crustal fluids. Geochim. Cosmochim. Acta 68, 2207 (2004).

28. Oelkers, E. H., Poitrasson, F.: An experimental study of the dissolution stoichiometry and rates of a natural monazite as a function of temperature from 50 to $230^{\circ} \mathrm{C}$ and pH from 1.5 to 10 . Chem. Geol. 191, 73 (2002).

29. Ewing, R. C., Wang, L. M.: Phosphates as nuclear waste forms. Rev. Mineral. Geochem. 48, 673 (2002).

30. Meldrum, A., Boatner, L. A., Weber, W. J., Ewing, R. C.: Radiation damage in zircon and monazite. Geochim. Cosmochim. Acta 62, 2509 (1998).

31. Meldrum, A., Boatner, L. A., Ewing, R. C.: A comparison of radiation effects in crystalline $\mathrm{ABO}_{4}$-type phosphates and silicates. Mineral. Mag. 64, 185 (2000).

32. Ewing, R. C., Meldrum, A., Wang, L. M., Wang, S.: Radiation induced amorphization. Rev. Mineral. Geochem. 39, 319 (2000).

33. Anthony, J. W., Bideaux, R. A., Bladh, K. W., Nichols, M. C. (Eds.): Handbook of Mineralogy, Mineralogical Society of America, Chantilly, VA, USA (2000). http://www.handbookofmineralogy. org/.

34. Mesbah, A., Clavier, N., Elkaim, E., Gausse, C., Kacem, I. B., Szenknect, S., Dacheux, N.: Monoclinic form of the rhabdophane compounds: $\mathrm{REEPO}_{4} \cdot 0.667 \mathrm{H}_{2} \mathrm{O}$. Cryst. Growth Des. 1,5090 (2014).

35. Ni, Y. X., Hughes, J. M., Mariano, A. N.: Crystal chemistry of the monazite and xenotime structure. Am. Mineral. 80, 21 (1995).

36. Shannon, R. D.: Revised effective ionic radii and systematic studies of interatomic distances in halides and chalcogenides. Acta Crystallogr. A32, 751 (1976).

37. Boatner, L. A.: Synthesis, structure and properties of monazite, pretulite and xenotime. Rev. Mineral. Geochem. 48, 87 (2002). 
38. Cuney, M., Mathieu, R.: Extreme light rare earth element mobilization by diagenetic fluids in the geological environment of the Oklo natural reactor zones, Franceville basin, Gabon. Geology 28, 743 (2000).

39. Seydoux-Guillaume, A. M., Wirth, R., Nasdala, L., Gottschalk, M., Montel, J. M., Heinrich, W.: An XRD, TEM and Raman study of experimentally annealed natural monazite. Phys. Chem. Miner. 29, 240 (2002).

40. Seydoux-Guillaume, A. M., Wirth, R., Deutsch, A., Schärer, U.: Microstructure of 24 - 1928 Ma concordant monazites: implications for geochronology and nuclear waste deposits. Geochim. Cosmochim. Acta 68, 2517 (2004).

41. Lumpkin, G. R., Geisler-Wierwille, T.: Minerals and natural analogues. In: R. J. M. Konings (Ed.), Comprehensive Nuclear Materials, Elsevier Ltd., Amsterdam (2012), Vol. 5, p. 563.

42. Seydoux-Guillaume, A. M., Wirth, R., Ingrin, J.: Contrasting response of ThSiO4 and monazite to natural irradiation. Eur. J. Mineral. 19, 7 (2007).

43. Seydoux-Guillaume, A. M., Montel, J. M., Bingen, B., Bosse, V., de Parseval, P., Paquette, J. L., Janots, E., Wirth, R.: Lowtemperature alteration of monazite: fluid mediated coupled dissolution-precipitation, irradiation damage, and disturbance of the U-Pb and Th-Pb chronometers. Chem. Geol. 330-331, 140 (2012).

44. Montel, J. M., Razafimahatratra, D., Ralison, B., De Parseval, P., Thibault, M., Randranja, R.: Monazite from mountain to ocean: a case study from Trolognaro (Fort-Dauphin). Madag. Eur. J. Mineral. 23, 745 (2011).

45. Bregiroux, D., Lucas, S., Champion, E., Audubert, F., BernacheAssollant, D.: Sintering and microstructure of rare earth phosphate ceramics $\mathrm{REPO}_{4}$ with RE $=\mathrm{La}$, Ce or Y. J. Eur. Ceram. Soc. 26, 279 (2006).

46. Bregiroux, D., Audubert, F., Charpentier, T., Sakellariou, D., Bernache-Assollant, D.: Solid-state synthesis of monazite-type compounds $\mathrm{LnPO}_{4}(\mathrm{Ln}=\mathrm{La}$ to $\mathrm{Gd}$ ). Solid State Sci. 9, 432 (2007).

47. Popa, K., Konings, R. J. M.: High-temperature heat capacities of $\mathrm{EuPO}_{4}$ and $\mathrm{SmPO}_{4}$ synthetic monazites. Thermochim. Acta 445, 49 (2006).

48. Aloy, A. S., Kovarskaya, E. N., Koltsova, T. I., Samoylov, S. E., Rovnyi, S. I., Medvedev, G. M. Immobilisation of Am-241 formed under plutonium metal conversion into monazite-type ceramic. In: L. J. Lardine, G. B. Borisov (Eds.), Review of Excess Weapons Plutonium Disposition. LLNL Contract work in Russia, UCRLID-149341 (2002), pp. 141-5.

49. Ushakov, S., Helean, K., Navrotsky, A., Boatner, L.: Thermochemistry of rare-earth orthophosphates. J. Mater. Res. 16, 2623 (2001).

50. Huittinen, N., Arinicheva, Y., Schmitz, M., Neumeier, S., Stumpf, T.: Using $\mathrm{Eu}^{3+}$ as an atomic probe to investigate the local environment in $\mathrm{LaPO}_{4}-\mathrm{GdPO}_{4}$ monazite end-members. J. Colloid Interface Sci. 483, 139 (2016).

51. Terra, O., Clavier, N., Dacheux, N., Podor, R.: Preparation and characterization of lanthanum - gadolinium monazites as ceramics for radioactive waste storage. New J. Chem. 27, 957 (2003).

52. Popa, K., Konings, R. J. M., Geisler, T.: High-temperature calorimetry of $\left(\mathrm{La}_{1-\mathrm{x}} \mathrm{Ln}_{x}\right) \mathrm{PO}_{4}$ solid solutions. J. Chem. Thermodyn. 39, 236 (2007).

53. Brandt, F., Neumeier, S., Schuppik, T., Arinicheva, Y., Bukaemskiy, A., Modolo, G., Bosbach, D.: Conditioning of minor actinides in lanthanum monazite ceramics: a surrogate study with Europium. Prog. Nucl. Energy 72, 140 (2014).

54. Neumeier, S., Kegler, P., Arinicheva, Y., Shelyug, A., Kowalski, P. M., Schreinemachers, C., Navrotsky, A., Bosbach, D.: Thermochemistry of $\mathrm{La}_{1-\mathrm{x}} \mathrm{Ln}_{\mathrm{x}} \mathrm{PO}_{4}$-monazites ( $\mathrm{Ln}=\mathrm{Gd}$, Eu). J. Chem. Thermodyn. 105, 396 (2017).

55. Arinicheva, Y., Bukaemskiy, A., Neumeier, S., Modolo, G., Bosbach, D.: Studies on thermal and mechanical properties of monazite-type ceramics for the conditioning of minor actinides. Prog. Nucl. Energy 72, 144 (2014).

56. Zeng, P., Teng, Y., Huang, Y., Wu, L., Wang, X.: Synthesis, phase structure and microstructure of monazite-type $\mathrm{Ce}_{1-x} \mathrm{Pr}_{x} \mathrm{PO}_{4}$ solid solutions for immobilization of minor actinide neptunium. J. Nucl. Mater. 452, 407 (2014).

57. Bjorklund, C.W.: The preparation of $\mathrm{PuP}_{2} \mathrm{O}_{7}$ and $\mathrm{PuPO}_{4}$. J. Am. Chem. Soc. 79, 6347 (1958).

58. Burakov, B. E., Yagovkina, M. A., Garbuzov, V. M., Kitsay, A. A., Zirlin, V. A.: Self-irradiation of monazite ceramics: contrasting behavior of $\mathrm{PuPO}_{4}$ and (La,Pu)PO doped with $\mathrm{Pu}-238$. Mater. Res. Soc. Symp. Proc. 824, 219 (2004).

59. Rai, D., Felmy, A. R., Mason, M. J.: Solubility and ion activity product of $\mathrm{AmPO}_{4} \bullet \mathrm{xH}_{2} \mathrm{O}$. Radiochim. Acta 56, 7 (1992).

60. Aloy, A. S., Kovarskaya, E. N., Koltsova, T. I., Samoylov, S. E., Rovnyi, S. I., Medvedev, G. M., Jardine, L. J.: Immobilization of Am-241, formed under plutonium metal conversion, into monazite-type ceramics. Am. Soc. Mech. Eng. 3, 1833 (2002).

61. Bregiroux, D., Belin, R., Valenza, P., Audubert, F., BernacheAssollant, D.: Plutonium and americium monazite materials: solid state synthesis and X-ray diffraction study. J. Nucl. Mater. 366, 52 (2007).

62. Weigel, F., Haug, H.: Zur Kenntnis des Curium(III)phosphats. Radiochim. Acta 4, 227 (1965).

63. Keller, C., Walter, K. H.: Darstellung, Gitterkonstanten und chemische Eigenschaften einiger ternärer Oxide des Plutoniums, Americiums und Curiums vom Typ $\mathrm{Me}^{\mathrm{II \prime}} \mathrm{X}^{\vee} \mathrm{O}_{4}$. J. Inorg. Nucl. Chem. 27, 1253 (1965).

64. Holliday, K. S., Babelot, C., Walther, C., Neumeier, S., Bosbach, D., Stumpf, T.: Site-selective time resolved laser fluorescence spectroscopy of Eu and $\mathrm{Cm}$ doped $\mathrm{LaPO}_{4}$. Radiochim. Acta 100, 189 (2012).

65. Hobart, D. E., Begun, G. M., Haire, R. G., Hellwegel, H. E.: Raman spectra of the transplutonium orthophosphates and trimetaphosphates. J. Raman Spectrosc. 14, 59 (1983).

66. Bamberger, C. E., Haire, R. G., Hellwege, H. E., Begun, G. M.: Synthesis and characterization of crystalline phosphates of plutonium(III) and plutonium(IV). J. Less-Common Met. 97, 349 (1984).

67. Glorieux, B., Jorion, F., Montel, J. M., Matecki, M., Deschanels, X., Coutures, J. P.: Investigation of plutonium-239 conditioning in monazite and brabantite matrices: synthesis and characterization. In: Proceedings ATALANTE 2004, Nîmes, France (2004), 032-04, pp. 1-6.

68. Popa, K., Raison, P. E., Martel, L., Martin, P. M., Prieur, D., Solari, P. L., Bouëxière, D., Konings, R. J. M., Somers, J.: Structural investigations of Pu"l phosphate by X-ray diffraction, MAS-NMR and XANES spectroscopy. J. Solid State Chem. 230, 169 (2015).

69. Jardin, R., Pavel, C. C., Raison, P. E., Bouëxière, D., Santa-Cruz, H., Konings, R. J. M., Popa, K.: The high-temperature behaviour of $\mathrm{PuPO}_{4}$ monazite and some other related compounds. J. Nucl. Mater. 378, 167 (2008). 
70. Begg, B. D., Vance, E. R., Conradson, S. D.: The incorporation of plutonium and neptunium in zirconolite and perovskite. J. Alloys Compd. 271-273, 221 (1998).

71. Popa, K., Colineau, E., Wastin, F., Konings, R. J. M.: The low-temperature heat capacity of $\left(\mathrm{Pu}_{0.1} \mathrm{La}_{0.9}\right) \mathrm{PO}_{4}$. Solid State Commun. 144, 74 (2007).

72. Arinicheva, Y., Popa, K., Scheinost, A. C., Rossberg, A., DiesteBlanco, O., Raison, P., Cambriani, A., Somers, J., Neumeier, S., Bosbach, D.: Structural investigations of $(\mathrm{La}, \mathrm{Pu}) \mathrm{PO}_{4}$ monazite solid solutions: XRD and XAFS study. J. Nucl. Mater. 493, 404 (2017).

73. Zhang, Y., Vance, E. R.: Plutonium in monazite and brabantite: diffuse reflectance spectroscopy study. J. Nucl. Mater. 375, 311 (2008).

74. Clavier, N., Dacheux, N., Wallez, G., Quarton, G.: Hydrothermal methods as a new way of actinide phosphate preparation. Mater. Res. Soc. Symp. Proc. 985, 169 (2007).

75. Mesbah, A., Clavier, N., Elkaim, E., Szenknect, S., Dacheux, N.: In pursuit of the rhabdophane crystal structure: form the hydrated monoclinic $\mathrm{LnPO}_{4} \cdot 0.667 \mathrm{H}_{2} \mathrm{O}$ to the hexagonal $\mathrm{LnPO}_{4}(\mathrm{Ln}=\mathrm{Nd}$, Sm, Gd, Eu and Dy). J. Solid State Chem. 249, 221 (2017).

76. Mooney, R. C. L.: X-ray diffraction study of cerous phosphate and related crystals. Acta. Cryst. 3, 337 (1950).

77. Lucas, S., Champion, E., Bernache-Assollant, D., Leroy, G.: Rare earth phosphate powders $\mathrm{RePO}_{4} \cdot n \mathrm{H}_{2} \mathrm{O}(\mathrm{Re}=\mathrm{La}$, Ce or Y $)$ - Part II. Thermal behavior. J. Solid State Chem. 177, 1312 (2004).

78. du Fou de Kerdaniel, E., Clavier, N., Dacheux, N., Terra, O., Podor, R.: Actinide solubility-controlling phases during the dissolution of phosphate ceramics. J. Nucl. Mater. 362, 451 (2007).

79. Gausse, C., Szenknect, S., Qin, D. W., Mesbah, A., Clavier, N., Neumeier, S., Bosbach, D., Dacheux, N.: Determination of the solubility of rhabdophanes $\mathrm{LnPO}_{4} \cdot 0.667 \mathrm{H}_{2} \mathrm{O}(\mathrm{Ln}=\mathrm{La}$ to $\mathrm{Dy})$. Eur. J. Inorg. Chem. 28, 4615 (2016).

80. Assaaoudi, H., Ennaciri, A., Rulmont A.: Vibrational spectra of hydrated rare earth orthophosphates. Vib. Spectrosc. 25, 81 (2001).

81. Jonasson, R. C.: DTA study of the rhabdophane to monazite transformation in rare earth (La-Dy) phosphates. Thermochim. Acta 108, 65 (1986).

82. Neumeier, S., Arinicheva, Y., Clavier, N., Podor, R., Bukaemskiy, A., Modolo, G., Dacheux, N., Bosbach D.: The effect of the synthesis route of monazite precursors on the microstructure of sintered pellets. Prog. Nucl. Energy 92, 298-305 (2016).

83. Peiffert, C., Brouand, M., Cuney, M., Podor, R.: La monazite-de l'indicateur de fertilité des granites pour les granites. Rapport CEA-R-5748, 103-8 (1996).

84. Podor R.: Synthèse et caractérisation des monazites uranifères et thorifères. PhD thesis of Université Henri Poincaré Nancy, France, No: 94 NAN10404 (1994).

85. Bregiroux, D., Popa, K., Wallez, G.: Crystal chemistry of $M^{\prime \prime} M^{\prime \prime V}\left(\mathrm{PO}_{4}\right)_{2}$ double monophosphates. J. Solid State Chem. 230, 26 (2015).

86. Gramaccioli, C., Segalstad, T.: A uranium- and thorium-rich monazite from a south-alpine pegmatite at Piona, Italy. Am. Mineral. 63, 757 (1978).

87. Popa, K., Bregiroux, D., Konings, R. J. M., Goudera, T., Popa, A. F., Geisler, T., Raison, P. E.: The chemistry of the phosphates of barium and tetravalent cations in the 1:1 stoichiometry. J. Solid State Chem. 180, 2346 (2007).

88. Wallez, G., Bregiroux, D., Popa, K., Raison, P. E., Apostolidis, C., Lindqvist-Reis, P., Konings, R. J. M., Popa, A. F.: $\mathrm{BaAn}{ }^{\mathrm{lV}}\left(\mathrm{PO}_{4}\right)_{2}$
$\left(A n^{1 v}=\right.$ Th, Np $)$ - a new family of layered double phosphates. Eur. J. Inorg. Chem. 1/2011, 110 (2011).

89. Graeber, E. J., Rosenzweig, A.: The crystal structures of yavapaiite, $\mathrm{KFe}\left(\mathrm{SO}_{4}\right)_{2}$, and goldichite $\mathrm{KFe}\left(\mathrm{SO}_{4}\right)_{2}\left(\mathrm{H}_{2} \mathrm{O}\right)_{4}$. Am. Mineral. 56, 1917 (1971).

90. Linthout, K.: Tripartite division of the system 2 REEPO $_{4}$ - $\mathrm{CaTh}\left(\mathrm{PO}_{4}\right)_{2}-2 \mathrm{ThSiO}_{4}$, discreditation of brabantite, and recognition of cheralite as the name for members dominated by CaTh $\left(\mathrm{PO}_{4}\right)_{2}$. Can. Mineral. 45, 503 (2007).

91. Beall, G., Boatner, L., Mullica, D., Milligan, W.: The structure of cerium orthophosphate, a synthetic analogue of monazite. J. Inorg. Nucl. Chem. 43, 101 (1981).

92. Popa, K., Wallez, G., Raison, P. E., Bregiroux, D., Apostolidis, C., Lindqvist-Reis, P., Konings, R. J. M.: $\operatorname{SrNp}\left(\mathrm{PO}_{4}\right)_{2}$ : an original ordered modification of cheralite. Inorg. Chem. 49, 6904 (2010).

93. Podor, R., Cuney, M.: Experimental study of Th-bearing $\mathrm{LaPO}_{4}$ $\left(780^{\circ} \mathrm{C}, 200 \mathrm{MPa}\right)$ : implications for monazite and actinide orthophosphate stability. Am. Mineral. 82, 765 (1997).

94. Dusausoy, Y., Ghermani, N.-E., Podor, R., Cuney, M.: Lowtemperature ordered phase of $\mathrm{CaU}\left(\mathrm{PO}_{4}\right)_{2}$ : synthesis and crystal structure. Eur. J. Mineral. 8, 667-673 (1996).

95. Podor, R., Cuney, M., Trung, C. N.: Experimental study of the solid solution between monazite-( $\mathrm{La})$ and $\left(\mathrm{Ca}_{0.5} \mathrm{U}_{0.5}\right) \mathrm{PO}_{4}$ at $780^{\circ} \mathrm{C}$ and $200 \mathrm{MPa}$. Am. Mineral. 80, 1261 (1995).

96. Terra, O., Dacheux, N., Clavier, N., Podor, R., Audubert, F.: Preparation of optimized uranium and thorium bearing brabantite or monazite/brabantite solid solutions. J. Am. Ceram. Soc. 91, 3673 (2008).

97. Tabuteau, A., Pagès, M., Livet, J., Musikas, C.: Monazite-like phases containing transuranium elements (neptunium and plutonium). J. Mater. Sci. Lett. 7, 1315 (1988).

98. Raison, P. E., Jardin, R., Bouëxière, D., Konings, R. J. M., Geisler, T., Pavel, C. C., Rebizant, J., Popa, K.: Structural investigation of the synthetic $\mathrm{CaAn}\left(\mathrm{PO}_{4}\right)_{2}(\mathrm{An}=\mathrm{Th}$ and $\mathrm{Np})$ cheralitelike phosphates. Phys. Chem. Miner. 35, 603 (2008).

99. Bregiroux, D., Terra, O., Audubert, F., Dacheux, N., Serin, V., Podor, R., Bernache-Assollant, D.: Solid-state synthesis of monazite-type compounds containing tetravalent elements. Inorg. Chem. 46, 10372 (2007).

100. Poitrasson, F., Chenery, S., Bland, D. J.: Contrasted monazite hydrothermal alteration mechanisms and their geochemical implications. Earth Planet Sci. Lett. 145, 79 (1996).

101. Terra, O.: Incorporation d'actinides tétravalents dans trois matrices phosphatées: britholite, monazite/brabantite et Phosphate-Diphosphate de Thorium (Bêta-PDT). PhD-thesis, Université Paris Sud-Paris XI, Paris (2005).

102. Deschanels, X., Picot, V., Glorieux, B., Jorion, F., Peuget, S., Roudil, D., Jégou, C., Broudic, V., Cachia, J. N., Advocat, T., Den Auwer, C., Fillet, C., Coutures, J. P., Hennig, C., Scheinost, A.: Plutonium incorporation in phosphate and titanate ceramics for minor actinide containment. J. Nucl. Mater. 352, 233 (2006).

103. Brandel, V., Dacheux, N.: Chemistry of tetravalent actinide phosphates-part II. J. Solid State Chem. 177, 4755 (2004).

104. Qin, D., Mesbah, A., Gausse, C., Szenknect, S., Dacheux, N., Clavier, N.: Incorporation of thorium in the rhabdophane structure: synthesis and characterization of $\mathrm{Ca}_{x} \mathrm{Th}_{\mathrm{x}} \mathrm{Pr}_{1-2 \mathrm{x}} \mathrm{PO}_{4} \cdot \mathrm{nH}_{2} \mathrm{O}$ solid solutions. J. Nucl. Mater. 492, 88 (2017).

105. Bénard, P., Brandel, V., Dacheux, N., Jaulmes, S., Launay, S., Lindecker, C., Genet, M., Louër, D., Quarton, M.: $\mathrm{Th}_{2}\left(\mathrm{PO}_{4}\right)_{4} \mathrm{P}_{2} \mathrm{O}_{7}$, 
a new thorium phosphate: synthesis, characterization, and structure determination. Chem. Mater. 8, 181 (1996).

106. Dacheux, N., Podor, R., Chassigneux, B., Brandel, V., Genet, M.: Actinides immobilization in new matrices based on solid solution: $\mathrm{Th}_{4-\mathrm{x}} \mathrm{M}_{\mathrm{x}}^{\mathrm{IV}}\left(\mathrm{PO}_{4}\right)_{4} \mathrm{P}_{2} \mathrm{O}_{7} \cdot\left(\mathrm{M}^{\mathrm{IV}}={ }^{238} \mathrm{U},{ }^{239} \mathrm{Pu}\right)$. J. Alloys Compd. 271-273, 236 (1998).

107. Dacheux, N., Podor, R., Brandel, V., Genet, M.: Investigations of systems $\mathrm{ThO}_{2}-\mathrm{MO}_{2}-\mathrm{P}_{2} \mathrm{O}_{5}(\mathrm{M}=\mathrm{U}, \mathrm{Ce}, \mathrm{Zr}, \mathrm{Pu})$. Solid solutions of thorium-uranium (IV) and thorium-plutonium (IV) phosphatediphosphates. J. Nucl. Mater. 252, 179 (1998).

108. Dacheux, N., Thomas, A. C., Brandel, V., Genet, M.: Investigations of systems $\mathrm{ThO}_{2}-\mathrm{NpO}_{2}-\mathrm{P}_{2} \mathrm{O}_{5}$. Solid solutions of thorium-neptunium (IV) and thorium-plutonium (IV) phosphatediphosphates. J. Nucl. Mater. 257, 108 (1998).

109. Brandel, V., Dacheux, N., Genet, M., Podor, R.: Hydrothermal synthesis and characterization of the thorium phosphate hydrogenphosphate, thorium hydroxide phosphate, and dithorium oxide phosphate. J. Solid State Chem. 159, 139 (2001).

110. Qin, D., Gausse, C., Szenknect, S., Mesbah, A., Clavier, N., Dacheux, N.: Solubility product of the thorium phosphate hydrogen-phosphate hydrate $\left(\mathrm{Th}_{2}\left(\mathrm{PO}_{4}\right)_{2}\left(\mathrm{HPO}_{4}\right) \cdot \mathrm{H}_{2} \mathrm{O}, \mathrm{TPHPH}\right)$. J. Chem. Thermodyn. 114, 151 (2017).

111. Clavier, N., Dacheux, N., Podor, R.: Synthesis, characterization, sintering, and leaching of $\beta$-TUPD/monazite radwaste matrices. Inorg. Chem. 45, 220 (2006).

112. Dacheux, N., Grandjean, S., Rousselle, J., Clavier, N.: Hydrothermal method of preparation of actinide(IV) phosphate hydrogenphosphate hydrates and study of their conversion into actinide(IV) phosphate diphosphate solid solutions. Inorg. Chem. 46, 10390 (2007).

113. Boyer, L., Savariault, J.-M., Carpena, J., Lacout, J.-L.: A neodymium-substituted britholite compound. Acta Crystallogr. C 54, 1057 (1998).

114. Sere, V.: Géochimie des minéraux néoformés à Oklo (Gabon), histoire géologique du bassin d'Oklo: une contribution pour les études de stockages géologiques de déchets radioactifs, Université de Paris VII, Paris (1996).

115. Terra, O., Dacheux, N., Audubert, F., Podor, R.: Synthesis and characterization of thorium-bearing britholites. J. Nucl. Mater. 352, 224 (2006).

116. Terra, O., Audubert, F., Dacheux, N., Guy, C., Podor, R.: Synthesis and characterization of uranium-bearing britholites. J. Nucl. Mater. 366, 70 (2007).

117. Bulanov, E. N., Wang, J., Knyazev, A. V., White, T., Manyakina, M. E., Baikie, T., Lapshin, A. N., Dong, Z.: Structure and thermal expansion of calcium-thorium apatite, $\left[\mathrm{Ca}_{4}\right]^{\mathrm{F}}\left[\mathrm{Ca}_{2} \mathrm{Th}_{4}\right]^{\mathrm{T}}\left[\left(\mathrm{SiO}_{4}\right)_{6}\right] \mathrm{O}_{2}$. Inorg. Chem. 54, 11356 (2015).

118. Boyer, L., Piriou, B., Carpena, J., Lacout, J.: Study of sites occupation and chemical environment of $\mathrm{Eu}^{3+}$ in phosphate-silicates oxyapatites by luminescence. J. Alloys Compd. 311, 143 (2000).

119. Achille, V. L.: Etude par modélisation atomistique de l'incorporation de lanthanides dans le réseau cristallin d'une apatite phosphocalcique, Université Paris VI, Paris (1999).

120. Meis, C.: Computational study of plutonium-neodymium fluorobritholite $\mathrm{Ca}_{9} \mathrm{Nd}_{0.5} \mathrm{Pu}_{0.5}\left(\mathrm{SiO}_{4}\right)\left(\mathrm{PO}_{4}\right)_{5} \mathrm{~F}_{2}$ thermodynamic properties and threshold displacement energies. J. Nucl. Mater. 289, 167 (2001).

121. Vance, E. R., Ball, C. J., Begg, B. D., Carter, M. L., Day, R. A., Thorogood, G. J.: Pu, U, and Hf incorporation in Gd silicate apatite. J. Am. Ceram. Soc. 86, 1223 (2003).
122. Brownfield, M. E., Foord, E. E., Sutley, S. J., Botinelly, T.: Kosnarite, $\mathrm{KZr}_{2}\left(\mathrm{PO}_{4}\right)_{3}$, a new mineral from Mount Mica and Black Mountain, Oxford County, Maine. Am. Mineral. 78, 653 (1993).

123. Orlova, A. I., Kitaev, D. B., Orlova, M. P., Bykov, D. M., Orlova, V. A., Tomilin, S. V., Lizin, A. A., Lukinich, A. N., Stefanovsky, S. V.: Synthesis and investigations of the phosphates of Th, U, Np, $\mathrm{Pu}, \mathrm{Am}$, and lanthanides with monazite, zircon, kosnarite and langbeinite mineral-like structures. In: R. Alvarez, N. D. Bryan, I. May (Eds.), Recent Advances in Actinide Science (Special Publication No. 305), RSC Publishing, Cambridge, UK (2006), p. 454.

124. Kato, T.: The crystal structure of florencite. Neues Jahrb. Mineral. Monatsh. 5, 227 (1990).

125. Montel, J.-M.: Minerals and design of new waste forms for conditioning nuclear waste. C. R. Geosci. 343, 230 (2011).

126. Byrappa, K.: Preparative methods and growth of rare earth phosphates. Prog. Cryst. Growth 13, 163 (1986).

127. Orlova, A. I., Kitaev, D. B., Kemenov, D. V., Orlova, M. P., Kazantsev, G. N., Samoilov, S. G., Kurazhkovskaya, V. S.: Synthesis and crystal-chemical properties of phosphates B" $R^{\prime \prime \prime} M^{\prime v}\left(\mathrm{PO}_{4}\right)_{3}$ containing $f, d$, and alkaline-earth elements. Radiochemistry 45, 103 (2003).

128. Boyer, L., Carpena, J., Lacout, J.: Synthesis of phosphate-silicate apatites at atmospheric pressure. Solid State Ion. 95, 121 (1997).

129. Boakye, E. E., Mogilevsky, P.: Synthesis of nanosized spherical rhabdophane particles. J. Am. Ceram. Soc. 88, 2740 (2005).

130. Lucas, S., Champion, E., Bregiroux, D., Bernache-Assollant, D., Audubert, F.: Rare earth phosphate powders $\mathrm{RePO}_{4} \cdot n \mathrm{H}_{2} \mathrm{O}$ $(\operatorname{Re}=\mathrm{La}, \mathrm{Ce}$ or $\mathrm{Y})-$ part I. Synthesis and characterization. J. Solid State Chem. 177, 1302 (2004).

131. Meyssamy, H., Riwotzki, K., Kornovski, A., Naused, S., Hause, M.: Wet-chemical synthesis of doped colloidal nanomaterials: particles and fibers of $\mathrm{LaPO}_{4}: \mathrm{Eu}, \mathrm{LaPO}_{4}: \mathrm{Ce}$, and $\mathrm{LaPO}_{4}: \mathrm{Ce}, \mathrm{Tb}$. Adv. Mater. 11, 840 (1999).

132. Bingham, P. A., Hand, R. J., Stennett, M. C., Hyatt, N. C., Harrison, M. T.: The use of surrogates in waste immobilization studies: a case of plutonium. Mater. Res. Soc. Symp. Proc. 1107, 421 (2008).

133. Lide, D. R.: CRC Handbook of Chemistry and Physics, 72 nd ed. CRC Press, Boca Raton (1991-1992), Section 8, p. 17-22.

134. Vance, E. R., Dorji, T. C., Gregg, D. J.: Synroc development past and present applications. MRS Energy Sustain. 4, https:// doi.org/10.1557/mre.2017.9 (2017).

135. Gombert, D., Richardson, J. R.: Cold crucible induction melter design and development. Nucl. Technol. 14, 301 (2003).

136. Sobolev, I. A., Stefanovsky, S. V., Yudintsev, B. I., Nikonov, B. S., Mokhov, A. V.: Study of melted Synroc doped with simulated high-level waste. In: W. J. Gray, I. R. Triay (Eds.), Scientific Basis for Nuclear Waste Management XX, Materials Research Society, Warrendale, PA (1997), p. 363.

137. Sobolev, I. A., Stefanovsky, S. V., Emelianenko, B. I., Yudintsev, S., Vance, E. R., Jostsons, A.: Comparative study of Synroc-C ceramics produced by hot-pressing and inductive melting. In: W. J. Gray, I. R. Triay (Eds.), Scientific Basis for Nuclear Waste Management XX. Materials Research Society, Warrendale, PA (1997), p. 371.

138. Yudintsev, S. V., Stefanovsky, S. V., Kalenova, M. Y., Nikonov, B. S., Nikol'skii, M. S., Koshcheev, A. M., Shchepin, A. S.: Matrices for immobilization of the rare earth-actinide waste 
fraction, synthesized by cold crucible induction melting. Radiochemistry 57, 321 (2015).

139. Vance, E. R.: Ceramic waste forms. In: R. J. M. Konings (Ed.), Comprehensive Nuclear Materials, Elsevier Ltd., Amsterdam (2012), Vol. 5, p. 485.

140. Li, H., Zhang, Y., McGlinn, P. J., Moricca, S., Begg, B. D., Vance, E. R.: Characterisation of stainless steel-synroc interactions under hot isostatic pressing (HIPing) conditions. J. Nucl. Mater. 355, 136 (2006).

141. Zhang, Y., Li, H., McGlinn, P. J., Yang, B., Begg, B. D.: Stainless steel/glass-ceramic interactions under hot isostatic pressing (HIPing) conditions. J. Nucl. Mater. 375, 315 (2008).

142. Zhang, Y., Li, H., Moricca, S. J.: Pyrochlore-structured titanate ceramics for immobilisation of actinides: hot isostatic pressing (HIPing) and stainless steel/waste form interactions. Nucl. Mater. 377, 470 (2008).

143. Ma, J., Teng, Y., Wu, L., Zhang, K., Huang, Y., Zhao, X., Wang, G.: Effect of sintering technique on mechanical property and chemical durability of $\mathrm{Ce}_{0.5} \mathrm{Pr}_{0.5} \mathrm{PO}_{4}$ ceramics. Ceram. Int. 41, 14597 (2015).

144. Bregiroux, D., Audubert, F., Bernache-Assollant, D.: Densification and grain growth during solid state sintering of $\mathrm{LaPO}_{4}$. Ceram. Int. 35, 1115 (2009).

145. McCarthy, G. J., White, W. B., Pfoertsch, D. E.: Synthesis of nuclear waste monazites: ideal actinide hosts for geologic disposal. Mater. Res. Bull. 13, 1239 (1978).

146. Babelot, C., Bukaemskiy, A., Neumeier, S., Modolo, G., Bosbach, D.: Crystallization processes, compressibility, sinterability and mechanical properties of La-monazite-type ceramics. J. Eur. Ceram. Soc. 37, 1681 (2017).

147. Morgan, P., Housley, R., Davis, J., DeHaan, M.: Chemical and Ceramic Methods Toward Safe Storage of Actinides, Rockwell Scientific, Thousand Oaks, CA (2005).

148. Ma, J., Teng, Y., Huang, Y., Wu, L., Zhang, K., Zhao, X.: Effects of sintering process, $\mathrm{pH}$ and temperature on chemical durability of $\mathrm{Ce}_{0.5} \mathrm{Pr}_{0.5} \mathrm{PO}_{4}$ ceramics. J. Nucl. Mater. 465, 550 (2015).

149. Teng, Y., Wang, X., Huang, Y., Wu, L., Zeng, P.: Hot-pressure sintering, microstructure and chemical durability of $\mathrm{Ce}_{0.5} \mathrm{Eu}_{0.5} \mathrm{PO}_{4}$ monazite ceramics. Ceram. Int. 41, 10057 (2015).

150. Teng, Y., Zeng, P., Huang, Y., Wu, L., Wang, X.: Hot-pressing of monazite $\mathrm{Ce}_{0.5} \mathrm{Pr}_{0.5} \mathrm{PO}_{4}$ ceramic and its chemical durability. J. Nucl. Mater. 465, 482 (2015).

151. Zhao, X., Teng, Y., Wu, L., Huang, Y., Ma, J., Wang, G.: Chemical durability and leaching mechanism of $\mathrm{Ce}_{0.5} \mathrm{Eu}_{0.5} \mathrm{PO}_{4}$ ceramics: effects of temperature and $\mathrm{pH}$ values. J. Nucl. Mater. 466, 187 (2015).

152. Zhao, X., Teng, Y., Yang, H., Huang, Y., Ma, J.: Comparison of microstructure and chemical durability of $\mathrm{Ce}_{0.9} \mathrm{Gd}_{0.1} \mathrm{PO}_{4}$ ceram ics prepared by hot-press and pressureless sintering. Ceram. Int. 41, 11062 (2015).

153. Du, A., Qu, Z. X., Wan, C. L., Han, R. B., Pan, W.: In effects of processing parameters of SPS on the densification and texture of $\mathrm{LaPO}_{4}$ ceramics. Key Engineering Materials, Trans. Tech. Publ. 368-372, 1059 (2008).

154. Du, A., Wan, C., Qu, Z., Pan, W.: Thermal conductivity of monazite-type $\mathrm{REPO}_{4}(\mathrm{RE}=\mathrm{La}, \mathrm{Ce}, \mathrm{Nd}, \mathrm{Sm}, \mathrm{Eu}, \mathrm{Gd})$. J. Am. Ceram. Soc. 92, 2687 (2009).

155. Du, A., Wan, C., Qu, Z., Wu, R., Pan, W.: Effects of texture on the thermal conductivity of the $\mathrm{LaPO}_{4}$ monazite. J. Am. Ceram. Soc. 93, 2822 (2010).
156. Popa, K., Cologna, M., Martel, L., Staicu, D., Cambriani, A., Ernstberger, M., Raison, P. E., Somers, J.: CaTh $\left(\mathrm{PO}_{4}\right)_{2}$ cheralite as a candidate ceramic nuclear waste form: spark plasma sintering and physicochemical characterization. J. Eur. Ceram. Soc. 36, 4115 (2016).

157. Dacheux, N., Chassigneux, B., Brandel, V., Le Coustumer, P., Genet, M., Cizeron, G.: Reactive sintering of the thorium phosphate-diphosphate. Study of physical, thermal, and thermomechanical properties and chemical durability during leaching tests. Chem. Mater. 14, 2953 (2002).

158. Clavier, N., Dacheux, N., Martinez, P., Du Fou de Kerdaniel, E., Aranda, L., Podor, R.: Sintering of $\beta$-thorium-uranium(IV) phosphate-diphosphate solid solutions from low-temperature precursors. Chem. Mater. 16, 3357 (2004).

159. Audubert, F., Bernache-Assolant, D.: Sintering investigation of silicate-apatite $\left[\mathrm{Ca}_{9} \mathrm{Nd}\left(\mathrm{SiO}_{4}\right)\left(\mathrm{PO}_{4}\right)_{5} \mathrm{~F}_{2}\right]$, In: P. Vincenzini (Ed.), Advances in Science and Technology - Proceedings of the $10^{\text {th }}$ International Ceramics Congress - CIMTEC 2002. Part B, 31, 61, Techna, Faenza (2003).

160. Hirsch, A., Kegler, P., Alencar, I., Ruiz-Fuertes, J., Shelyug, A., Peters, L., Schreinemachers, C., Neumann, A., Neumeier, S., Liermann, H.-P., Navrotsky, A., Roth, G.: Structural, vibrational, and thermochemical properties of the monazite-type solid solution $\mathrm{La}_{1-\mathrm{x}} \mathrm{Pr}_{x} \mathrm{PO}_{4}$. J. Solid State Chem. 245, 82 (2017).

161. de Biasi, R. S., Fernandes, A. A. R., Oliveira, J. C. S.: Cell volumes of $\mathrm{LaPO}_{4}-\mathrm{CePO}_{4}$ solid-solutions. J. Appl. Crystallogr. 20, 319 (1987).

162. Hou, Z. Y., Zhang, M. L., Wang, L. L., Lian, H. Z., Chai, R. T., Zhang, C. M., Cheng, Z. Y., Lin, J.: Preparation and luminescence properties of $\mathrm{Ce}^{3+}$ and/or $\mathrm{Tb}^{3+}$ doped $\mathrm{LaPO}_{4}$ nanofibers and microbelts by electrospinning. J. Solid State Chem. 182, 2332 (2009).

163. Heuser, J.: Keramiken des Monazit-Typs zur Immobilisierung von minoren Actinoiden und Plutonium. Ph.D. thesis, RWTH Aachen University, Aachen (2015).

164. Wang, X., Teng, Y., Huang, Y., Wu, L., Zeng, P.: Synthesis and structure of $\mathrm{Ce}_{1-\mathrm{x}} \mathrm{Eu}_{\mathrm{x}} \mathrm{PO}_{4}$ solid solutions for minor actinides immobilization. J. Nucl. Mater. 451, 147 (2014).

165. Yang, H., Teng, Y., Ren, X., Wu, L., Liu, H., Wang, S., Xu, L.: Synthesis and crystalline phase of monazite-type $\mathrm{Ce}_{1-x} \mathrm{Gd}_{x} \mathrm{PO}_{4}$ solid solutions for immobilization of minor actinide curium. J. Nucl. Mater. 444, 39 (2014).

166. Begun, G. M., Beall, G. W., Boatner, L. A., Gregor, W. J.: Raman spectra of the rare earth orthophosphates. J. Raman Spectrosc. 11, 273 (1981).

167. Podor, R.: Raman spectra of the actinide-bearing monazites. Eur. J. Mineral. 7, 1353 (1995).

168. Silva, E. N., Ayala, A. P., Guedes, I., Paschoal, C. W. A., Moreira, R. L., Loong, C. K., Boatner, L. A.: Vibrational spectra of monazite-type rare-earth orthophosphates. Opt. Mater. 29, 224 (2006).

169. Thust, A., Arinicheva, Y., Haussühl, E., Ruiz-Fuertes, J., Bayarjargal, L., Vogel, S. C., Neumeier, S., Winkler, B.: Physical properties of $\mathrm{La}_{1-\mathrm{x}} \mathrm{Eu}_{\mathrm{x}} \mathrm{PO}_{4}, 0 \leq \mathrm{x} \leq 1$, monazite-type ceramics. J. Am. Ceram. Soc. 98, 4016 (2015).

170. Kowalski, P. M., Beridze, G., Vinograd, V., Bosbach, D.: Heat capacities of lanthanide and actinide monazite-type ceramics. J. Nucl. Mater. 464, 147 (2015).

171. Jahn, S., Kowalski, P. M.: Theoretical approaches to structure and spectroscopy of earth materials. Rev. Mineral. Geochem. 78, 691 (2014). 
172. Blanca-Romero, A., Kowalski, P. M., Beridze, G., Schlenz, H., Bosbach, D.: DFT+U studies of monazite-type ceramics: predicting structural and thermodynamic parameters. J. Comput. Chem. 35, 1339 (2014).

173. Beridze, G., Birnie, A., Koniski, S., Ji, Y., Kowalski, P. M.: DFT+U as a reliable method for efficient ab initio calculations of nuclear materials. Prog. Nucl. Energy 92, 142 (2016).

174. Perdew, J. P., Ruzsinszky, A., Csonka, G. I., Vydrov, O. A., Scuseria, G. E., Constantin, L. A., Zhou, X., Burke, K.: Restoring the density-gradient expansion for exchange in solids and surfaces. Phys. Rev. Lett. 100, 136406 (2008).

175. Cococcioni, M., de Gironcoli, S.: Linear response approach to the calculation of the effective interaction parameters in the LDA + U method. Phys. Rev. B 71, 035105 (2005).

176. Rustad, J. R.: Density functional calculations of the enthalpies of formation of rare-earth orthophosphates. Am. Mineral. 97, 791 (2012).

177. Kowalski, P. M., Beridze, G., Li, Y., Ji, Y., Friedrich, C., Şaşıoğlu, E., Blügel, S.: Feasible and reliable ab initio approach to computation of materials relevant for nuclear waste management. Ceram. Trans. 258, 207 (2016).

178. Kowalski, P. M., Beridze, G., Ji, Y., Li, Y.: Towards reliable modeling of challenging f-electrons bearing materials: experience from modeling of nuclear materials. MRS Adv. 2, 491 (2017).

179. Feng, J., Xiao, B., Zhou, R., Pan, W.: Anisotropy in elasticity and thermal conductivity of monazite-type $\mathrm{REPO}_{4}(\mathrm{RE}=\mathrm{La}, \mathrm{Ce}, \mathrm{Nd}$, $\mathrm{Sm}$, Eu and Gd) from first-principles calculations. Acta Mater. 61, 7364 (2013).

180. Wang, J., Zhou, Y., Lin, Z.: First-principles elastic stiffness of $\mathrm{LaPO}_{4}$ monazite. Appl. Phys. Lett. 87, 051902 (2005).

181. Ali, K., Arya, A., Ghosh, P. S., Dey, G. K.: A first principle study of the pressure dependent elastic properties of monazite $\mathrm{LaPO}_{4}$. In: M. S. Shekhawat, S. Bhardwaj, B. Suthar (Eds.): International Conference on Condensed Matter and Applied Physics (ICC2015) (2016), p. 1728.

182. Kowalski, P. M., Li, Y.: Relationship between the thermodynamic excess properties of mixing and the elastic moduli in the monazite-type ceramics. J. Eur. Ceram. Soc. 36, 2093 (2016).

183. Ji, Y., Beridze, G., Li, Y., Kowalski, P. M.: Large scale simulations of nuclear waste materials. Energy Procedia 127, 416 (2017).

184. Gomis, O., Lavina, B., Rodriguez-Hernandez, P., Munoz, A., Errandonea, R., Errandonea, D., Bettinelli, M.: High-pressure structural, elastic, and thermodynamic properties of zircon-type $\mathrm{HoPO}_{4}$ and $\mathrm{TmPO}_{4}$. J. Phys. Condens. Matter 29, 095401 (2017).

185. Kowalski, P. M., Ji, Y., Li, Y., Arinicheva, Y., Beridze, G., Neumeier, S., Bukaemskiy, A., Bosbach, D.: Simulation of ceramic materials for nuclear waste management: case of $\mathrm{La}_{1-\mathrm{x}} \mathrm{Eu}_{\mathrm{x}} \mathrm{PO}_{4}$ solid solution. Nucl. Instrum. Methods B 393, 68 (2017).

186. López-Solano, J., Rodriguez-Hernandez, P., Munoz, A., Gomis, O., Santamaria-Perez, D., Errandonea, D., Manjon, F. J., Kumar R. S., Stavrou, E., Raptis, C.: Theoretical and experimental study of the structural stability of $\mathrm{TbPO}_{4}$ at high pressures. Phys. Rev. B 81, 144126 (2010).

187. Stavrou, E., Tatsi, A., Raptis, C., Efthimiopoulos, I., Syassen, K., Munoz, A., Rodriguez-Hernandez, P., Lopez-Solano, J., Hanfland, M.: Effects of pressure on the structure and lattice dynamics of $\mathrm{TmPO}_{4}$ : experiments and calculations. Phys. Rev. B 85, 024117 (2012).
188. Shein, I. R., Shalaeva, E. V.: Pressure-induced zircon to monazite phase transition in $\mathrm{Y}_{1-x} \mathrm{La}_{\mathrm{x}} \mathrm{PO}_{4}$ : first-principles calculations. J. Struct. Chem. 57, 1513 (2016).

189. Bauer, J. D., Hirsch, A., Bayarjargal, L., Peters, L., Roth, G., Winkler, B.: Schottky contribution to the heat capacity of monazite type ( $\mathrm{La}, \mathrm{Pr}) \mathrm{PO}_{4}$ from low temperature calorimetry and fluorescence measurements. Chem. Phys. Lett. 654, 97 (2016).

190. Li, Y., Kowalski, P. M., Beridze, G., Blanca-Romero, A., Ji, Y., Vinograd, V. L., Gale, J., Bosbach, D.: Atomistic simulations of ceramic materials relevant for nuclear waste management: cases of monazite and pyrochlore. Ceram. Trans. 255, 165 (2016).

191. Ji, Y., Kowalski, P. M., Neumeier, S., Deismann, G., Kulriya, P. K., Gale, J. D.: Atomistic modeling and experimental studies of radiation damage in monazite-type $\mathrm{LaPO}_{4}$ ceramics. Nucl. Instrum. Methods B. 393, 54 (2017).

192. Jolley, K., Asuvathraman, R., Smith, R.: Inter-atomic potentials for radiation damage studies in $\mathrm{CePO}_{4}$ monazite. Nucl. Instrum. Methods B 393, 93 (2017).

193. Huittinen, N., Arinicheva, Y., Kowalski, P. M., Vinograd, V. L., Neumeier, S., Bosbach, D.: Probing structural homogeneity of $\mathrm{La}_{1-x} \mathrm{Gd}_{\mathrm{x}} \mathrm{PO}_{4}$ monazite-type solid solutions by combined spectroscopic and computational studies. J. Nucl. Mater. 486, 148 (2017).

194. Gao, F., Xiao, H. Y., Zhou, Y. G., Devanathan, R., Hua, S. Y., Li, Y. L., Sun, X., Khaleel, M. A.: Ab initio study of defect properties in $\mathrm{YPO}_{4}$. Comput. Mater. Sci. 54, 170 (2012).

195. Markus, I. M., Adelstein, N., Asta, M., De Jonghe, L. C.: Ab initio calculation of proton transport in $\mathrm{DyPO}_{4}$. J. Phys. Chem. C 118, 5073 (2014).

196. Chase, M. W. J.: NIST-JANAF thermochemical tables. American Inst. of Physics, New York (1998).

197. Robie, R. A., Hemingway, B. S., Fisher, J. R.: Thermodynamic Properties of Minerals and Related Substances at 298.15 K and 1 bar ( $10^{5}$ pascals) Pressure and at Higher Temperatures, U.S. Geological survey bulletin 2131, Washington, 459 pp. (1978).

198. Yungman, V. S.: Thermal Constants of Substances, Begell House, Danbury, CT (1999).

199. Navrotsky, A.: Progress and new directions in calorimetry: a 2014 perspective. J. Am. Ceram. Soc. 97, 3349 (2014).

200. Navrotsky, A.: Mineralogy, materials science, energy, and environment: a 2015 perspective. Am. Mineral. 100, 674 (2015).

201. Sarge, S. M., Höhne, G. W. H., Hemminger, W. F.: Calorimetry: Fundamentals, Instrumentation and Applications, Wiley-VCH Verlag GmbH \& Co KGaA, Weinheim (2014).

202. Sedmidubský, D., Beneš, O., Konings, R. J. M.: High temperature heat capacity of $\mathrm{Nd}_{2} \mathrm{Zr}_{2} \mathrm{O}_{7}$ and $\mathrm{La}_{2} \mathrm{Zr}_{2} \mathrm{O}_{7}$ pyrochlores. J. Chem. Thermodyn. 37, 1098 (2005).

203. Navrotsky, A.: Progress and new directions in high temperature calorimetry. Phys. Chem. Miner. 2, 89 (1977).

204. Navrotsky, A.: Progress and new directions in high temperature calorimetry revisited. Phys. Chem. Miner. 24, 222 (1997).

205. Navrotsky, A.: High temperature oxide melt calorimetry of oxides and nitrides. In: "Huffman Lecture at ICCT 2000". J. Chem. Thermodyn. 33, 859 (2001).

206. Levchenko, A., Marchin, L., Parlouer, P. L., Navrotsky, A.: The new high-temperature Setaram AlexSYS calorimeter and thermochemistry of alpha-CuMnO${ }_{4}$. ITAS Bull. 2, 91 (2009). 
207. Ushakov, S. V., Navrotsky, A.: Experimental approaches to the thermodynamics of ceramics above $1500^{\circ} \mathrm{C}$. J. Am. Ceram. Soc. 95, 1463 (2012).

208. Popa, K., Sedmidubský, D., Beneš, O., Thiriet, C., Konings, R. J. M.: The high-temperature heat capacity of $\mathrm{LnPO}_{4}(\mathrm{Ln}=\mathrm{La}, \mathrm{Ce}$, Gd) by drop calorimetry. J. Chem. Thermodyn. 38, 825 (2006).

209. Popa, K., Jutier, F., Wastin, F., Konings, R. J. M.: The heat capacity of $\mathrm{NdPO}_{4}$. J. Chem. Thermodyn. 38, 1306 (2006).

210. Navrotsky, A., Lee, W., Mielewczyk-Gryn, A., Ushakov, S. V., Anderko, A., Wu, H., Riman, R. E.: Thermodynamics of solid phases containing rare earth oxides. J. Chem. Thermodyn. 88, 126 (2015).

211. Gavrichev, K. S., Gurevich, V. M., Ryumin, M. A., Tyrin, A. V., Komissarova, l. N.: Low-temperature heat capacity and thermodynamic properties of $\mathrm{PrPO}_{4}$. Geochem. Int. 54, 362 (2016).

212. Ushakov, S. V., Navrotsky, A., Farmer, J. M., Boatner, L. A.: Thermochemistry of the alkali rare-earth double phosphates, $\mathrm{A}_{3} \mathrm{RE}\left(\mathrm{PO}_{4}\right)_{2}$. J. Mater. Res. 19, 2165 (2004).

213. Konings, R. J. M., Walter, M., Popa, K.: Excess properties of the $\left(\mathrm{Ln}_{2-2 x} \mathrm{Ca}_{\mathrm{x}} \mathrm{Th}_{\mathrm{x}}\right)\left(\mathrm{PO}_{4}\right)_{2}(\mathrm{Ln}=\mathrm{La}, \mathrm{Ce})$ solid solutions. J. Chem. Thermodyn. 40, 1305 (2008).

214. Rawat, D., Phapale, S., Mishra, R., Dash, S.: Thermodynamics studies on charge-coupled substituted synthetic monazite. J. Nucl. Mater. 487, 406 (2017).

215. Geisler, T., Popa, K., Konings, R. J. M.: Evidence for lattice strain and non-ideal behavior in the $\left(\mathrm{La}_{1-\mathrm{x}} \mathrm{Eu}_{\mathrm{x}}\right) \mathrm{PO}_{4}$ solid solution from $X$-ray diffraction and vibrational spectroscopy. Front. Earth Sci. 4, Article 64 (2016).

216. Li, Y., Kowalski, P. M., Blanca-Romero, A., Vinograd, V., Bosbach, D.: Ab initio calculation of excess properties of $\mathrm{La}_{1-\mathrm{x}}(\mathrm{Ln}, \mathrm{An})_{\mathrm{x}} \mathrm{PO}_{4}$ solid solutions. J. Solid State Chem. 220, 137 (2014).

217. Mogilevsky, P., Boakye, E. E.: Solid solubility and thermal expansion in a $\mathrm{LaPO}_{4}-\mathrm{YPO}_{4}$ system. J. Am. Ceram. Soc. 90, 1899 (2007).

218. Thiriet, C., Konings, R. J. M., Wastin, F.: Low temperature heat capacity of $\mathrm{PuPO}_{4}$. J. Nucl. Mater. 344, 56 (2005).

219. Beneš, O., Popa, K., Reuscher, V., Zappia, A., Staicu, D., Konings, R. J. M.: High temperature heat capacity of $\mathrm{PuPO}_{4}$ monazite-analogue. J. Nucl. Mater. 418, 182 (2011).

220. Popa, K., Shvareva, T., Mazeina, L., Colineau, E., Wastin, F., Konings, R. J. M., Navrotsky, A.: Thermodynamic properties of $\mathrm{CaTh}\left(\mathrm{PO}_{4}\right)_{2}$ synthetic cheralite. Am. Mineral. 93, 1356 (2008).

221. Meldrum, A., Cherniak, D.: Ion beams in the geological sciences. In: H. Bernas (Ed.), Materials Science with Ion Beams. Topics in Applied Physics, Springer, Berlin Heidelberg (2010), Vol. 116, p. 317.

222. Deschanels, X., Seydoux-Guillaume, A., Magnin, V., Mesbah, A., Tribet, M., Moloney, M., Serruys, Y., Peuget, S.: Swelling induced by alpha decay in monazite and zirconolite ceramics: a XRD and TEM comparative study. J. Nucl. Mater. 448, 184 (2014).

223. Luo, J. S., Liu, G. K.: Microscopic effects of self-radiation damage in ${ }^{244} \mathrm{Cm}$-doped $\mathrm{LuPO}_{4}$ crystals. J. Mater. Res. 16, 366 (2001)

224. Weber, W. J., Ewing, R. C., Wang, L.-M.: The radiation-induced crystalline to amorphous transition in zircon. J. Mater. Res. 9, 688 (1994).

225. Karioris, F. G., Gowda, K. A., Cartz, L.: Heavy ion bombardment of monoclinic $\mathrm{ThSiO}_{4}$, ThO ${ }_{2}$ and monazite. Radiat. Eff. Lett. 58, 1 (1981).
226. Meldrum, A., Wang, L. M., Ewing, R. C.: Ion beam induced amorphisation of monazite. Nucl. Instrum. Methods B 116, 220 (1996).

227. Boatner, L., Sales, B.: Monazite. In: W. Lutze, R. C. Ewing, (Eds.), Radioactive Waste Forms for the Future, North Holland, Amsterdam (1988).

228. Meldrum, A., Boatner, L. A., Ewing, R. C.: Displacive radiation effects in monazite- and zircon-structure orthophosphates. Phys. Rev. B 56, 13805 (1997).

229. Meldrum, A., Boatner, L. A., Zinkle, S. J., Wang, S.-X., Wang, L.-M., Ewing, R. C.: Effects of dose rate and temperature on the crystallie-to-metamict transformation in the $\mathrm{ABO}_{4}$ orthosilicates. Can. Mineral. 37, 207 (1999).

230. Weber, W. J., Roberts, F. P.: A review of radiation effects in solid nuclear waste forms. Nucl. Technol. 60, 178 (1983).

231. Nasdala, L., Grotzschel, R., Probst, S., Bleisteiner, B.: Irradiation damage in monazite-(Ce): an example to establish the limits of Raman confocality and depth resolution. Can. Mineral. 48, 351 (2010).

232. Picot, V., Deschanels, X., Peuget, S., Glorieux, B., SeydouxGuillaume, A. M., Wirth, R.: Ion beam radiation effects in monazite. J. Nucl. Mater. 381, 290 (2008).

233. Biersack, J. P., Haggmark, L. G.: A Monte Carlo computer program for the transport of energetic ions in amorphous targets. Nucl. Instrum. Methods 174, 257 (1980).

234. Ziegler, J. F., Biersack, J. P., Ziegler, M. D.: The stopping and range of ions in matter. Ion Implantation Press (2008), 398 pp.

235. Ziegler, J. F., Ziegler, M. D., Biersack, J. P.: SRIM - the stopping and range of ions in matter. Nucl. Instrum. Methods B 268, 1818 (2010).

236. Tamain, C., Özgümüs, A., Dacheux, N., Garrido, F., Thomé, L.: Effects of irradiation on the thorium phosphate diphosphate ceramics and consequences on its dissolution. J. Nucl. Mater. 352, 217 (2006).

237. Tamain, C., Dacheux, N., Garrido, F., Habert, A., Barré, N., Özgümüs, A., Thomé, L.: Consequences of the ion beam irradiation on the chemical durability of thorium phosphate diphosphate - kinetics study. J. Nucl. Mater. 358, 190 (2006).

238. Tamain, C., Dacheux, N., Garrido, F., Thomé, L.: Irradiation effects on thorium phosphate diphosphate: chemical durability and thermodynamic study. J. Nucl. Mater. 362, 459 (2007).

239. Tamain, C., Garrido, F., Thomé, L., Dacheux, N., Özgümüs, A.: Structural behavior of $\beta$-thorium phosphate diphosphate ( $\beta$ TPD) irradiated with ion beams. J. Nucl. Mater. 373, 378 (2008).

240. Robisson, A. C., Dacheux, N., Aupiais, J.: Influence of the pH on the dissolution of TPD and associated solid solutions. J. Nucl. Mater. 306, 134 (2002).

241. Clavier, N., du Fou de Kerdaniel, E., Dacheux, N., Le Coustumer, P., Drot, R., Ravaux, J., Simoni, E.: Behavior of thorium-uranium (IV) phosphate-diphosphate sintered samples during leaching tests. Part II. Saturation processes. J. Nucl. Mater. 349, 304 (2006).

242. USDOE. MCC-1 Static Test: Nuclear Waste Materials Handbook. US-Report-No. DOE/TIC 11400, Material Characterization Centre, Hanford (1984).

243. Pierce, E. M., McGrail, B. P., Martin, P. F., Marra, J., Arey, B. W., Geiszler, K. N.: Accelerated weathering of high-level and plutonium-bearing lanthanide borosilicate waste glasses under hydraulically unsaturated conditions. Appl. Geochem. 22, 1841 (2007). 
244. Claparede, L., Clavier, N., Dacheux, N., Mesbah, A., Martinez, J., Szenknect, S., Moisy, P.: Multiparametric dissolution of thorium-cerium dioxide solid solutions. Inorg. Chem. 50, 11702 (2011).

245. Horlait, D., Tocino, F., Clavier, N., Dacheux, N., Szenknect, S.: Multiparametric study of $\mathrm{Th}_{1-x} \mathrm{Ln}_{\mathrm{x}} \mathrm{O}_{2-x / 2}$ mixed oxides dissolution in nitric acid media. J. Nucl. Mater. 429, 237 (2012).

246. Horlait, D., Claperede, L., Tocino, F., Clavier, N., Ravaux, J., Szenknect, S., Podor, R., Dacheux, N.: Environmental SEM monitoring of $\mathrm{Ce}_{1-x} \mathrm{Ln}_{\mathrm{x}} \mathrm{O}_{2-x / 2}$ mixed-oxide microstructural evolution during dissolution. J. Mater. Chem. A 2, 5193 (2014).

247. Claperede, L., Tocino, F., Szenknect, S., Mesbah, A., Clavier, N., Moisy, P., Dacheux, N.: Dissolution of $\mathrm{Th}_{1-x} \mathrm{U}_{\mathrm{x}} \mathrm{O}_{2}$ : effects of chemical composition and microstructure. J. Nucl. Mater. 457, 304 (2015).

248. Langmuir, D.: Aqueous Environmental Geochemistry, Upper Saddle River, N.J., Prentice Hall (1997), p. 600.

249. du Fou de Kerdaniel, E.: Etude de la dissolution de britholites et de solutions solides monazite/brabantite dopées avec des actinides. Thèse de l'Université Paris Sud-Paris XI, Paris (2007).

250. Sales, B., White, C., Boatner, L.: A comparison of the corrosion characteristics of synthetic monazite and borosilicate glass containing simulated nuclear defense waste. Nucl. Chem. Waste Manage. 4, 281 (1983).

251. Ishida, M., Kikuchi, K., Yanagi, T., Terai, R.: Leaching behavior of crystalline phosphate waste forms. Nucl. Chem. Waste Manage. 6, 127 (1986).

252. Boatner, L., Abraham, M., Rappaz, M.: Analogs of monazite for the storage of radioactive wastes. Trans. Am. Nucl. Soc. 35, 186 (1980).
253. Veilly, E., du Fou de Kerdaniel, E., Roques, J., Dacheux, N., Clavier, N.: Comparative behavior of britholites and monazite/ brabantite solid solutions during leaching tests: a combined experimental and DFT approach. Inorg. Chem. 47, 10971 (2008).

254. Thomas, A., Dacheux, N., Le Coustumer, P., Brandel, V., Genet, M.: Kinetic and thermodynamic study of the thorium phosphate-diphosphate dissolution. J. Nucl. Mater. 281, 91 (2000).

255. Thomas, A. C., Dacheux, N., Le Coustumer, P., Brandel, V., Genet, M.: Kinetic and thermodynamic studies of the dissolution of thorium-uranium (IV) phosphate-diphosphate solid solutions. J. Nucl. Mater. 295, 249 (2001).

256. Dacheux, N.: Chimie des phosphates d'actinides tétravalents. Le PDT en tant que matrice d'immobilisation des actinides. Habilitation à Diriger des Recherches, Université Paris-Sud-11 (2002).

257. Dacheux, N., Clavier, N., Ritt, J.: Behavior of thorium-uranium (IV) phosphate-diphosphate sintered samples during leaching tests. Part I - kinetic study. J. Nucl. Mater. 349, 291 (2006).

258. Dacheux, N., du Fou de Kerdaniel, E., Clavier, N., Podor, R., Aupiais, J., Szenknect, S.: Kinetics of dissolution of thorium and uranium doped britholites ceramics. J. Nucl. Mater. 404, 33 (2010).

259. Deissmann, G., Filby, A., Neumeier, S., Bosbach, D.: Solubility of lanthanidephosphates $\left(\mathrm{LnPO}_{4}\right)$ and aqueous lanthanide speciation under repository relevant conditions. In: Symposium on Scientific Basis for Nuclear Waste Management XXXIX, MRS-Conference, Montpellier, France (2015). 